\title{
BEYOND PANOPTICISM: ON THE RAMIFICATIONS OF SURVEILLANCE IN A CONTEMPORARY PROFESSIONAL SETTING
}

\author{
By \\ Marion Brivot, Ph.D. \\ John Molson School of Business \\ 1455 boul. de Maisonneuve ouest \\ Concordia University \\ Montréal (Québec) \\ Canada H3G $1 \mathrm{M} 8$ \\ Tel.: (514) 848-2424 ext. 2753 \\ E-mail: mbrivot@jmsb.concordia.ca \\ Yves Gendron, Ph.D., C.A. \\ Faculté des sciences de l'administration \\ Pavillon Palasis-Prince \\ 2325, rue de la Terrasse \\ Local 6224 \\ Université Laval \\ Québec City (Québec) \\ Canada G1V 0A6 \\ Tel.: (418) 656-2131 ext. 2431 \\ E-mail: yves.gendron@fsa.ulaval.ca
}

March 2011

We thank practitioners who supported this research and allowed us to gather data on certain aspects of their professional lives. We also benefited from the comments made by participants at the 2010 Alternative Accounts Conference (Toronto), the 2010 Annual Congress of the European Accounting Association (Istanbul), the 2010 "Comptabilité, multivocalité et diversité" Workshop (Rouen Business School), and the research workshop organized by the Centre de Recherche en Comptabilite (CRC) of CNAM (Paris, December 2010). Finally, we acknowledge the financial support of the Social Sciences and Humanities Research Council of Canada. 


\title{
BEYOND PANOPTICISM: ON THE RAMIFICATIONS OF SURVEILLANCE IN A CONTEMPORARY PROFESSIONAL SETTING
}

\begin{abstract}
This paper provides fieldwork evidence, which solidifies an emerging view in literature, regarding the limitations of the panoptical metaphor in informing meaningfully and productively the analysis of contemporary surveillance and control. Our thesis is that the panopticon metaphor, which conceives of the organization as a bounded enclosure made up of divisible, observable and calculable spaces, is becoming less and less relevant in the age of contemporary surveillance technologies. Through a longitudinal socio-ethnographic study of the ramifications of surveillance ensuing from the implementation of a computerized knowledge management system (KMS) in a Parisian tax/law firm, our analysis points to the proliferation of lateral networks of surveillance having developed in the aftermath of implementation. In this complex and unstable constellation of rhizomatical controls, peers are involved in scrutinizing the validity of one another's work, irrespective of the office's hierarchies and official lines of specialization. As a result, games of visibility (exhibitionism), observation (voyeurism) and secrecy (hiding one's work from the KMS) abound in the office. One of our main conclusions is to emphasize the pertinence of apprehending control and surveillance from angles that take into account the ambiguities, complexities and unpredictability of human institutions, especially in digitalized environments.
\end{abstract}

Keywords: Collegial control; Information technology; Knowledge management; Panopticon; Professional service organizations; Surveillance. 


\section{BEYOND PANOPTICISM: ON THE RAMIFICATIONS OF SURVEILLANCE IN A CONTEMPORARY PROFESSIONAL SETTING}

\section{Introduction}

Everyday life is subject to monitoring, checking, scrutinizing. It is hard to find a place, or an activity, that is shielded or secure from some purposeful tracking, tagging, listening, watching, recording or verification device. (Lyon, 2001, p. 1)

Surveillance constitutes a prime feature of today's society (Lyon, 2001), which is significantly preoccupied with a variety of dangers and risks, from earthquakes to moral sins (Douglas, 1992). Organizations and governments establish sophisticated systems to control perceived areas of uncertainty, both internally (e.g., originating from employees) and externally (e.g., exchange rate fluctuations). These technologies can have significant effects, for instance in generating a collective sense of confidence in mastering Nature and in influencing the individual's subjectivity (Lyon, 2001).

Individuals and organizations are often confronted in their daily undertakings to technologies of surveillance. One intriguing example is the recent story of Goldman Sachs' former trader known as "Fabulous Fab". Fabulous Fab's private correspondence with his girlfriend, sent by email through the company's messaging system, became a key component in one of the largest fraud investigations in history filed by the US Securities and Exchange Commission (Reuters, 2010a). These emails revealed that "Fabulous Fab" anticipated the subprime market crisis coming and took advantage of the situation by continuing to sell "toxic" financial products to "poor little subprime borrowers". We know from Giddens (1985, p. 14) that everyday surveillance is "endemic to modern societies"; the peculiarity in Fabulous Fab's story is how information technologies, such as messaging servers, increase the potentialities of surveillance - even though the technologies are not primarily designed for surveillance. Although new technological developments (e.g., GPS, biometry, Radio Frequency Identification (RFID) chips) proliferate society and are developed for a variety of different reasons, they make it possible to stretch the conceptual boundaries of surveillance.

Underlying the spread of surveillance in modern society is acceleration in the development of centres of control and calculation (Latour, 1987). These centres are typically considered as powerful institutions, able to gather extensive data on targets of surveillance and to make 
significant decisions (Lyon, 2001). Some of these decisions are even automated, as was the case in the 6 May 2010 so-called "Flash Crash" at the New York Stock Exchange. According to the joint report of the US Securities and Exchange Commission (SEC) and the Commodity Futures Trading Commission, issued on September $30^{\text {th }} 2010$, a mutual fund complex "initiated a sell program to sell a total of 75,000 E-Mini contracts as a hedge to an existing equity position" (page 2). ${ }^{1}$ As these trades were executed in the futures market, automatic trading programs designed to sell stocks at specified levels kicked in and contributed to the stock market's downward spiral. This, in turn, led the Dow Jones Industrial Average to fall by 900 points, the biggest one-day point decline in this stock market index's history (Reuters, 2010b):

I think the machines just took over. There's not a lot of human interaction. [...] We've known that automated trading can run away from you and I think that's what we saw happen today. (Charlie Smith, chief investment officer at Fort Pitt Capital Group). (The Huffington Post, 2010).

Accordingly, recent literature on surveillance highlights that information technologies have significantly impacted the scope of surveillance on society. In particular, the Big Brother metaphor is increasingly questioned as a result of the explosion of these technological developments:

"Global surveillance" is not the result of a Machiavellian project whose end is to take control over individual minds. The hypothesis of a Big (or even a small) Brother is very far from what [is currently happening]. In fact, the very concept of "control" constitutes a fantasy - that of a radical and ultimate manipulation of individuals. [...] This infantile view of surveillance is currently imploding and fissuring due to the proliferation of non-hierarchical, polycentric, and multi-objective surveillance technologies. (Quessada \& Sadin, 2010, pp. 78-79, our translation)

In this paper, our ambition is to provide evidence that solidifies an emerging view in literature regarding the limitations of the panoptical metaphor in informing meaningfully and productively the analysis of contemporary surveillance (Bogard, 2006; Haggerty \& Ericson, 2000). The classic imagery of the "panopticon", quite prevalent in the managerial control literature, is predicated on a hierarchical view of control in which localized and specific targets of surveillance never know whether or not they are actively being watched - thereby leading them

\footnotetext{
${ }^{1}$ See: www.sec.gov/news/studies/2010/marketevents-report.pdf.
} 
to assume that they are constantly watched (e.g., Macintosh, 1994 - especially chapter 13; Miller \& O’Leary, 1987; Preston, 1989; Rahaman, Neu, \& Everett, 2010). ${ }^{2}$

While ideal-type panoptical control might be possible in prisons and, by extension, in traditional disciplinary institutions (e.g., houses of correction, asylums, mass-production factories, as well as certain types of schools and clinics), doubt can be cast on the extent to which the panopticon concept can be productively applied in domains permeated with information technologies. The latter transform significantly spatial relationships in society (Castells, 2001; Knights, Noble, Vurdubakis, \& Willmott, 2001; Lyon, 2001) to the point that it can be argued that the meaningfulness of the notion of enclosure, which is central to panopticism, is less obvious today (Martinez, 2011; Wood, 2007). Individuals are not devoid of resources in the face of hierarchical and digitalized power and they are able to abide, strengthen, resist and bypass complex systems of control and surveillance, as recognized by Foucault (1980) and documented in some accounting literature (Arnold, 1998; Dirsmith, Fischer, \& Samuel, 2005; Ezzamel, Willmott, \& Worthington, 2004; Froud, Williams, Haslam, Johal, \& Williams, 1998).

One of the key themes emphasized in recent literature on digitalized surveillance is that the imagery of the panopticon is less and less reflective of what surveillance today really is (e.g., Haggerty \& Ericson, 2000). Not only is resistance possible in such an environment, but individuals can also actively participate (wittingly or not) in their own visibility, thereby creating new potentialities of surveillance by others. As such, our paper extends a line of thinking developed by Miller and Rose (1990, p. 11) that states, "Technologies produce unexpected problems, are utilized for their own ends by those who are supposed to merely operate them, are hampered by under-funding, professional rivalries, and the impossibility of producing the technical conditions that would make them work-reliable statistics, efficient communication systems, clear lines of command, properly designed buildings, well framed regulations or whatever." Our paper, therefore, contributes to a discourse that provides a reflective and grounded counterpoint to the waves of unbridled optimism which often characterize the views that people have about the controllability of social relationships through formal and increasingly digitalized technologies of management and regulation.

\footnotetext{
${ }^{2}$ The imagery is also influential in popular literature. A search on Google of "management control and big brother" produced, on March 1 2011, 275,000 hits.
} 
To carry out the research, we utilize data gathered during a longitudinal socio-ethnographic investigation pertaining to the implementation of a knowledge management system (KMS) in one of the local offices of a large professional service firm, specializing in law. The system was formally aimed at managing the production of tax and legal opinion letters by rank-and-file lawyers within the confines of their local office. In principle, the KMS provides administrative partners with various data regarding lawyers' work, as well as the capacity to examine output conveniently from the comfort of one's desk. One of the most interesting points regarding the implementation of this technology of surveillance is the sheer amount of deviation it generated. For instance, an active lateral network of surveillance developed in the case firm, in which many lawyers were mobilizing the system to view others' output and pass judgment on it. Therefore, we developed these two research questions:

(1) What ramifications of surveillance ensue from the implementation of a KMS in the local office under study?

(2) How do office lawyers react to the constitution of these ramifications in their daily undertakings?

Professional settings constitute appropriate sites to study control and surveillance from a sociological perspective. While professionals are often viewed as individuals disposing of significant room to maneuver in their daily work (Freidson, 2001), they are more and more subject to the ascendancy of formal control mechanisms (Gendron \& Spira, 2009), not least because their work is increasingly produced and mediated through large organizations including governments, public corporations, and professional service firms (Suddaby, Gendron, \& Lam, 2009). Furthermore, society's increasing demand for transparency and trustworthiness following highly mediatised scandals involving professional responsibility (Sikka, 2009), has reinvigorated the debate about the modalities of professional control (Robson, Willmott, Cooper, $\&$ Puxty, 1994). From a different perspective, our focus on knowledge management is warranted since surveillance constitutes one of the central features of the basic philosophy which underlies the spread of KMSs in organizations (He, Fang, \& Wei, 2009), namely that, for each managerial issue, at least one best practice answer should be identified, codified, stored and disseminated for large-scale re-use within the organization.

Our paper solidifies the argument that targets of surveillance can contribute to the transformation, re-direction and ramification of the very mechanisms that aimed originally to 
undermine their own autonomy at work. In so doing, resistance and compliance are not diametrically opposed. Instead, they are dialectically intertwined through the actors' complex trajectories of life (Dirsmith et al., 2005). Our paper, therefore, answers the exhortation made by Arnold (1998), Dirsmith et al. (2005), Ezzamel et al. (2004) and Froud et al. (1998), in that management accounting research should focus more on the intertwined dynamics of compliance and resistance in studying the spread of control within organizations.

One of our main conclusions emphasizes the pertinence of understanding control and surveillance from angles that take into account the ambiguities, complexities and unpredictability of human institutions, especially in the context of rampant digitalization. Making sense of contemporary control through hierarchical panoptic imageries overshadows important nuances and subtleties that underlie the domain of social relationships.

The remainder of the paper is as follows. First, we review the sociological literature on computerized surveillance practices and argue that these practices cannot be understood productively through the classic panoptical lens. Second, we describe our research methods and field observations. In the last section, we present our conclusions and what we view as the paper's main theoretical implications.

\section{Networks of surveillance}

Surveillance matters. It contributes to social order, promotes certain interests, and reinforces certain socioeconomic divisions (Lyon, 2001). We rely especially on the writings of Michel Foucault in order to articulate the angle we use to examine agents' reactions to the deployment of a formal KMS. While Foucault's works cover a variety of topics such as prisons, sexuality and modes of government, one of the prime features of his research investigates how human beings become subjects (Foucault, 1983) through a range of disciplinary and surveillance devices that define, influence and regulate individuals (Bevir, 1999). Yet we recognize that relying on Foucault may seem paradoxical, given his prominent role in popularizing the panopticon. $^{3}$ Although our analysis brings to the fore limitations underlying the epistemological

\footnotetext{
${ }^{3}$ The extent to which Foucault's body of thoughts is internally and homogeneously coherent is a matter of debate in literature. Some have argued that his work is characterized by a number of unresolved paradoxes. For instance, Badiou (2003, p. 3) maintains the following: "In his middle period, Foucault argued that networks of disciplinary power not only reach the most intimate spaces of the subject, but actually produce what we call subjects. However,
} 
power of panoptical imagery in understanding digitalized surveillance, Foucault's larger body of work can be meaningfully mobilized in examining surveillance from a broader angle (Haggerty \& Ericson, 2000) that recognizes key minutiae, ramifications and complexities.

Foucault was particularly interested in the role of devices, such as disciplinary techniques and surveillance mechanisms, in influencing the ways in which people construct themselves and their environment - the ultimate aim of these control apparatuses being to forge docile bodies (Rabinow, 1984). Under such a perspective, the individual is not reducible to an internal and unchanging core of meaning; s/he is rather conceived of as being subject to an array of disciplinary influences (Townley, 1993). Through disciplinary power individuals come to be defined as objects which are measurable, manageable and transformable (Covaleski, Dirsmith, Heian, \& Samuel, 1998). Discipline is therefore conceived of as a set of practices and processes that aim to construct knowledge about the individual via processes of classification, codification, categorization and measurement (Townley, 1993). In particular, through disciplinary techniques, such as the examination or performance measurement records, subjects are individualized and rendered visible in a way that often compares, for example, their performance or behaviour to a norm or standard (e.g., the average) (Covaleski et al., 1998; Foucault, 1977). Being castigated as abnormal or outside the norm - or being fearful of being seen as abnormal - tends to incite effort to normalize and alter identity. Rabinow (1984) also points out that contemporary regimes of disciplinary power tend to deal expediently with abnormalities, through a range of corrective and therapeutic procedures.

The individual can, therefore, be understood as being both the product of the norm and the target of normalization (Covaleski et al., 1998). The influence of disciplinary techniques should not be downplayed as their domain of influence is not bounded to a specific time and space;

Foucault also said that power produces resistance. [...] If the subject - right down to its most intimate desires, actions and thoughts - is constituted by power, then how can it be a source of independent resistance?" Several academics (e.g., Han, 2002; Nealon, 2008) also claim an "evolution" between the Foucault of the mid-1970s and the Foucault of the 1980s. According to Nealon (2008, p. 4) "critics seem to have agreed that Foucault's midcareer work constituted a dead-end, a totalizing cage, an omnipresent panopticon with no possibility for any subjective or collective resistance." But in the 1980s, Foucault deals with the matter by assigning agency to those subjects who resist power. According to Han (2002), Foucault's later work (the History of Sexuality I and II) is no longer concerned with the idea of disciplinary power. While both periods have in common the question of how one is constructed as a subject, each focuses on different aspects of the subjectification process and on different historical periods. "It is not power but the subject that is the general theme of my research" (Foucault, 1982, p. 778). Our decision to rely on Foucault's theorizing of power as part of our conceptual base to examine the limitations of the panopticon concept in contemporary times is no coincidence. 
disciplinary techniques can render visible certain representations of behaviour which allow others to intervene at a distance (Neu \& Graham, 2006; Townley, 1994). For instance, accounting data allows headquarters managers to be made aware of specificities that originate from distant branches, and to make decisions or recommendations even when the managers never met or discussed the matter with local labour.

One of the metaphors used by Foucault (1977) to comprehend discipline, which is extensively cited in the accounting and control literature, is that of the panopticon, viewed as the archetype of social control, "What had once featured merely as an innovative and influential approach to prison architecture, produced by an eccentric social reformer, was reinvented by Foucault as a paradigmatic exemplar of modern discipline" (Lyon, 2001, p. 114). The panopticon concept is generally believed to originate from the work of Jeremy Bentham, who developed a prison design in which prisoners never know whether or not they are actively watched by prison guards. The overarching objective was to induce self-monitoring in prisoners, made observable through a specific configuration of space and bodies producing constant and uninterrupted surveillance, even when no one is watching prisoners (Dreyfus \& Rabinow, 1983). Although Bentham's panoptic prison was never actually built, the notion was discussed abundantly, thereby contributing to the development of a discourse about correction and control (Dreyfus \& Rabinow, 1983). Yet we need to be careful regarding the extent to which panopticism can be productively used in different times and places:

It [i.e., the panoptic schema] is - necessary modifications apart - applicable [...] to all establishments whatsoever, in which, within a space not too large to be covered or commanded by buildings, a number of persons are meant to be kept under inspection [...]. (Foucault, 1977, pp. 205-206)

The extent to which the deployment of panoptic technologies has engendered resistance across society is also a point of contention in literature. At times, Foucault even seems to suggest that panopticism implies omnipotence over the mind, "Without any physical instrument other than architecture and geometry, it [i.e., the panopticon] acts directly on individuals; it gives 'power of mind over mind"' (Foucault, 1977, p. 206). Yet it is no exaggeration to argue that panopticism constitutes today a central notion that people and academics often use to make sense of contemporary control while promoting an imagery of hierarchical power. In the words of Townley (1994, p. 139): 
Panopticism operates through hierarchical observation and normalizing judgement. Visibility from the centre captures the activities of the periphery in reports and registers, which then form the basis of comparative, evaluative judgements.

Various studies have investigated panopticism operating in society, from $18^{\text {th }}$ century factories (Carmona, Ezzamel, \& Gutíerrez, 1997, 2002) to today's world characterized with the accelerated development of computerized databases (Poster, 1997). Poster (1997) even maintains that digital databases are consistent with the notion of "superpanopticon", in which subjects constantly produce surveillance data by making numerous cell phone calls, Internet bookings, etc. The way in which Jeremy Bentham's panopticon becomes Poster's (1997) superpanopticon is through the obsolescence of geographical and physical enclosures, which become unnecessary thanks to information technologies. From this perspective, it is probably no exaggeration to maintain that, today escaping from the gaze of surveillance is very difficult, because wherever we are and whatever we do (using a credit card, using a nominative travel pass, checking in and out with a security pass at work, etc.), we leave a trail of digital records. There have even been discussions about the incorporation of RFID chips in human bodies - notably in Latin America where kidnapping is viewed as a major problem (news.cnet.com, 2003) - to allow real-time geographical positioning of everyone. In the words of Dreyfus and Rabinow (1983, p. 191), [super]panoptical technologies operate through a reversal of visibility, "whereas in monarchical regimes it was the sovereign who had the greatest visibility, under the institutions of bio-power it is those who are to be disciplined, observed, and understood who are made the most visible."

However, an emerging theme in surveillance literature is technological developments having increased the scope, nature and density of surveillance mechanisms, taking surveillance to a new level, for which the explanatory powers of the (super)panopticon metaphor are inherently limited. In the words of Haggerty and Ericson (2000, p. 607):

Foucault's analysis [reminds] us of the degree to which the proles have long been the subject of intense scrutiny. In fact, Foucault accentuates how it was precisely this population - which was seen to lack the self-discipline required by the emerging factory system - that was singled out for a disproportionate level of disciplinary surveillance. [...] Unfortunately, Foucault fails to directly engage contemporary developments in surveillance technology, focusing instead on transformations to eighteenth and nineteenth century total institutions. [...] Even authors predisposed to embrace many of Foucault's insights believe that rapid technological developments, 
particularly the rise of computerized databases, require us to rethink the panoptic metaphor.

In the following paragraphs, we describe several properties of current surveillance technologies that arguably diminish or moderate the relevance of the panopticon figure in understanding contemporary forms of control and power.

First, blogs and social networking websites such as Facebook or Twitter foster games of visibility and observation (e.g., exhibitionism and voyeurism) which engender diverse forms of social control. Data on the behaviour and profile of Internet users is collected, oftentimes covertly by other Internet users, "Information technologies [...] answer a fundamental human desire - that of knowing everything about everybody else, so as to be in control of our relationships" (Deglise, 2009, citing Tisseron, 2008, our translation). Not only do these lateral surveillance practices affect our private lives, but they impact the world of work. Stories in the press indicate employers dismissing employees because of defamatory statements written on Facebook pages (The Independent, 2008), as well as cases of employers checking for information on Facebook and Twitter that corroborates candidates' CVs (The New York Times, 2006). These emerging surveillance practices remain to be exhaustively documented and their implications for organizational control are yet to be analyzed. However, what can be highlighted is the absence of a central watching figure, unlike in the panoptical metaphor. Modern technologies of surveillance are operated by an unstable collective of actors with a variety of agendas, each focusing on diverse targets of control (Doyle, 2006).

Second, the target of surveillance has changed. Increased data storage capacities coupled with reduced cost of data storage have made it possible to keep track of data not only on the "deviant" and the "abnormal", as was the case in disciplinary enclosures in the $18^{\text {th }}$ and $19^{\text {th }}$ centuries, but of everyone by default, "You may well have done nothing out of the ordinary, let alone violated some rule or broken some law, yet your transactions, exchanges, conversations, movements and calls still come to the attention of agencies and organizations for whom these activities are significant" (Lyon 2001, p. 2). A typical illustration of the surveillance of everyone is the decision of the Parisian public transport organization, RATP, to issue nominative travel passes equipped with an RFID chip, by which the itineraries of the four million passengers who own the pass can be monitored. Data on passengers' travels is kept on RATP's servers for 48 
hours (news.fr.msn.com/m6-actualite, 2009). Quessada (2010, pp. 56-57, our translation) calls this far-reaching form of surveillance practice, "sub-veillance":

Surveillance signifies keeping one's eyes open. It means watching "over" [...]. From this perspective, the agent of surveillance, as overseer, always benefits from an episcopal position on the targets of surveillance, being able to see things from above. [...] "Sub-veillance", on the other hand, goes beyond surveillance because it is light, discreet, immaterial and omnipresent. "Sub" designates the most insidious side of it; it refers to the action of something which works from below the targets of surveillance. Databases are at the heart of this system. [...] Sub-veillance does not supervise from the overhanging position [...] of a power located above its subjects; instead it operates from the position of a "carpet" on which the subjects walk. It operates as a multidimensional digital web within which individuals live and disseminate information which makes their tracking possible, with a degree of subservience that no authoritarian power has ever dared to dream of.

Third, monitoring is no longer tightly constrained to specific geographical or temporal enclosures or "disciplinary blockades" (Armstrong 1994, p. 27). As maintained by Bogard (2006), the modern technologies of surveillance are less and less bounded to specific territories. Besides, they are no longer limited to the real-time monitoring of ongoing facts. While the panoptical architecture scrutinizes current data to detect the abnormalities of the present, new information technologies foresee the abnormalities of the future through trend analysis and simulation. In this context, computer modelling and simulation (e.g., neuromarketing, datamining) allow observation "before the fact" so to speak. Computer profiling, for instance, is designed to predict people's navigational preferences based on certain traits (e.g., age, gender). The implication for surveillance is that it becomes possible, to a certain extent, to send alerts before a reprehensible or deviant act is perpetrated. From this perspective, surveillance aims to eliminate problems before they emerge, "before they even have the chance to become problems" (Bogard, 2006, p. 60). Sadin (2010, p. 65) argues that the predictive mode of surveillance is especially encouraged through the terrorist mania which has developed since the turn of the century:

A significant shift occurred in the temporal mechanisms of surveillance. These mechanisms are no longer meant to verify compliance with laws and regulation or to detect delinquent behaviour from an ex post perspective; instead their aim is to create preventive algorithms in charge of sending alerts about what is likely to occur. 
One illustration is Google's claim that, thanks to new intelligent web crawlers, it can be determined when an individual is about to start looking for a job, two or three months before the person has even started to do so (Sadin, 2010, p. 65). The predictive gaze of present-day surveillance is emblematic of what Rouvroy and Berns (2010) have termed "algorithmic governmentality", that is to say a form of power-knowledge predicated on profiling practices and concerned with the prevention of certain types of behaviour. Yet the rise of algorism does not imply that surveillance is becoming solely interested with digital profiles and no longer with physical bodies. Data originating from the body (DNA, biometric, X-rays, AIDS testing) is increasingly gathered in a variety of places (Potte-Bonneville, 2010), including the workplace. Yet the relationship between current surveillance regimes and the physical body is not in line with a panoptical view of control:

The surveillant assemblage does not approach the body in the first instance as a single entity to be molded, punished, or controlled. [...] The surveillant assemblage standardizes the capture of flesh / information flows of the human body. It is not so much immediately concerned with the direct physical relocation of the human body (although this may be an ultimate consequence), but with transforming the body into pure information, such that it can be rendered more mobile and comparable. (Haggerty \& Ericson, 2000, pp. 612-613)

Information excerpted from the body is transformed and reassembled, through centres of calculation, into algorithmic strategies oriented towards the future. Algorithmic governmentality "is no longer aimed at mastering the present but at structuring the range of the possible. [...] The point is no longer to entice rational individuals to abide by the law but to affect them, at a preconscious level if possible, by anticipating what they could be or do" (Rouvroy \& Berns, 2010, pp. 93-94, our translation).

Fourth, unlike the panopticon which leaves little doubt as to the existence of a relatively clear surveillance project, there is no unified surveillance master plan underlying the proliferation of technologies, there is no central watching figure either. Modern technologies of surveillance are operated by an unstable collective of actors with a variety of agendas, each focusing on diverse targets of control (Doyle, 2006). Emails, blogs, internet forums, KMSs, social networking websites, public transportation passes, cell phones, etc., are often not primarily designed for surveillance. Yet, through these technological devices, the gaze of surveillance has expanded 
considerably, to the point that the hierarchy of observation, in which a few powerful agents watch the many through top-down scrutiny, is less and less reflective of today's realities. The mass media, for instance through reality television, have made it possible for the public to watch the privacy of a few individuals (Lyon, 2006). Another illustration relates to technologies such as video cameras and cell phones, which involve the general public in the monitoring of the powerful, for example through videos of police brutality broadcasted on television (Haggerty \& Ericson, 2000). Thus, people are encouraged to accept the creeping gaze of surveillance, in that it becomes a normal part of their everyday lives to see the behaviour of a few individuals being generally exposed for consumption. The viewing of the few by the many can even be experienced as a form of voyeurism from which the watchers get pleasure (Doyle, 2006).

Drawing on the above, the gaze of contemporary surveillance can be viewed as rhizomatic, "no major population groups stand irrefutably above or outside of the surveillant assemblage" (Haggerty \& Ericson, 2000, p. 618). Individuals, groups, organizations and governments, across all sectors of society, are involved both as agents and targets of surveillance. Importantly, no central actor can be understood as being "in power" of present-day surveillance; top-down hierarchy does not neatly fit a domain whose boundaries are ever-changing and hazy. Overseers can be continually overseen by others:

As it is multiple, unstable and lacks discernible boundaries or responsible governmental departments, the surveillant assemblage cannot be dismantled by prohibiting a particularly unpalatable technology. Nor can it be attacked by focusing criticism on a single bureaucracy or institution. In the face of multiple connections across myriad technologies and practices, struggles against particular manifestations of surveillance, as important as they might be, are akin to efforts to keep the ocean's tide back with a broom. (Haggerty \& Ericson, 2000, p. 609)

As a matter of fact, Foucault himself emphasized that power being only applied by those at the top of hierarchies (or watchtowers) to those at the bottom constitutes a simplifying conceptualization (Dreyfus \& Rabinow, 1983). In a seminal book published a few years after Discipline and Punish (1977), Foucault (1980) stresses that power and resistance are diffuse and operate through vast, complex and capillary networks. At the end of his life, Foucault (1983) even made it clear that some of the most important struggles in today's society consist of conflicts surrounding the subjection of individuals, "All these present struggles revolve around the question: Who are we? They are a refusal of these abstractions, of economic and ideological 
state violence, which ignore who we are individually, and also a refusal of a scientific or administrative inquisition which determines who one is" (Foucault, 1983, p. 781).

This feature of contemporary surveillance systems (i.e. the absence of a unified surveillance project) engenders important implications from the viewpoint of resistance, since potential opposition movements cannot readily identify hierarchical targets upon which they can direct their protest. Accordingly, in spite of the growing density of surveillance (or sub-veillance) practices, relatively little societal resistance has been observed, "Surveillance always carries with it some plausible justification that makes most of us content to comply. [...] The fact that the camera is installed in the bar or at the intersection in order to reduce rowdiness or road accidents seems reasonable enough. [...] The advantages of surveillance for its subjects are real, palpable, and undeniable. We readily accept the point of it, or we are resigned to what seems like innocent if sometimes annoying attempts to influence us or verify our identity" (Lyon, 2001, pp. 3-4). The fear of abnormality is not reflected in the behaviour of people who seem to be quite happy to collaborate in the potential tracking of their purchases and other activities. Besides, a form of discourse promoting egalitarian surveillance, which is often invoked when pointing out that modern surveillance does not target anyone in particular but is applicable to everyone, is thought to have eroded defiance and resistance:

The claim that individuals having nothing to hide should not fear surveillance, as well as the comfort of immediateness [...] and the increased status that one can psychologically derive from personal exhibition, have contributed largely to overcome the range of resistance against the unveiling of private life and intimacy. The triumph over privacy has been facilitated by the general practice of requiring some action from individuals in order to remove one's digital traces; digital traces are saved and kept in records by default. (Rouvroy \& Berns, 2010, p. 90, our translation)

Yet such quite pessimistic views regarding the potential for resistance in facilitating and translating into substantive change should not render us myopic to the relevance of taking resistance into account when studying surveillance from a holistic perspective.

Lastly, unlike Panoptical arrangements, which work with or without the consent of those being controlled, contemporary surveillance technologies can operate only if individuals diligently leave the digital traces (cell phone calls, emails, debit card payments, etc.) which serve to track and profile them. The agency of actors in opposing or circumventing surveillance should thus not be overshadowed, especially since individuals in the digital world are not devoid of 
resources to obstruct surveillance: a variety of avatars, logins and passwords open up potentialities for resisting against personal tracking and profiling (Gilliom, 2006). In the panoptical prison, the scarcity of resistance can reasonably be interpreted as the absence of shadow areas in which one can hide. But in the surveillance society, one can arguably hide by removing her/his digital traces, by avoiding traces to be left for scrutiny, or by jumbling them to the extent that they become untraceable. Resistance is therefore not beyond the abilities of the targets of modern surveillance, although it needs to be recognized that resistance is often covert and made up of unorganized gestures. In other words, the technologies of surveillance do not exert a deterministic form of power on targets; their influence is always subjected to agency. Thus, studying how surveillance is experienced by subjects constitutes a legitimate endeavour in developing a better comprehension of what surveillance is and its influence on society (Gilliom, 2006).

Drawing on this line of thought, it can be argued that individuals are able, at least in principle, to refuse the imagery, values and interests which underlie disciplinary projects. Individuals can resist endeavours aimed at categorizing them in certain ways and interpreting their individuality in accordance with some dictated law of truth. While Foucault's panopticon does not do justice to the complexities of digitalized surveillance, the broader ideas that he developed on capillary power, discipline and ever-changing foyers of resistance remain pertinent. Haggerty and Ericson's (2000) surge of pessimism should, therefore, be nuanced. In spite of surveillance being increasingly enacted in complex and hazy ways, resistance is not beyond the scope of individuals. From this perspective, research is able, at least in theory, to provide individuals with an understanding of how they are subjected to the ascendancy of a variety of governing mechanisms, including those of modern and digitalized surveillance (Flyvbjerg, 2001). In light of this, we feel comfortable about our study being informed by Foucault's broader ideas regarding the production of subjects, especially the interplay between the notions of disciplinary power, visibility and resistance.

In sum, the general tone that emerges from the above body of sociological research contrasts with a hierarchical view of control as conveyed through the panoptical imagery. We maintain that this imagery, which conceives of the organization as a bounded enclosure made up of divisible, observable and calculable spaces (e.g., responsibility centres), is becoming less and less relevant (not to the point of being irrelevant, though) in the age of contemporary surveillance 
technologies. ${ }^{4}$ Surveillance today often does not imply the existence of an omnipotent watching agent. The economics of new information technologies make is possible to extend surveillance to everybody, thereby modifying the relationship between control and enclosure. The gaze of these technologies is no longer necessarily constrained to the detection of the abnormalities of the present, but can, instead, be oriented towards the prediction of behaviour. Therefore, control within organizations is likely to be significantly different from panoptic control when being viewed from a perspective that recognizes the complexities and ramifications that characterize the spread of digitalized technologies in organizational life. Accordingly, the present paper provides fieldwork evidence that various unanticipated forms of compliance and resistance have emerged in the case firm following management's attempt to extend surveillance over work through a centralized KMS. In particular, our findings solidify the argument that surveillance today should not be viewed as operating strictly in a hierarchical way, but capillary, through diverse webs of compliance and dissidence. The panoptical imagery, in its classic form, is limited in accounting for these processes.

\section{Method}

Following Flyvbjerg (2001), the key methodological principle underlying our investigation is that the examination of micro-practices in actors' day-to-day activities is warranted if we are to comprehend the complexities surrounding the interplay between power, discipline and resistance.

\footnotetext{
${ }^{4}$ This does not imply that accounting scholars having relied on Foucault failed to understand his works. While Armstrong (1994) and McKinlay and Pezet (2010) make this claim, our position is more nuanced on the matter. Mobilizing others' work, especially when the underlying body of thoughts is characterized with a high degree of sophistication as that of Foucault, constitutes a very complex act of adaptation and translation (Malsch, Gendron, \& Grazzini, 2011). We certainly do not want our argument to be understood as a claim of intolerance made by minstrels of orthodoxy. Moreover, most of the accounting scholars who cite Discipline and Punish (Foucault 1977), particularly part 3, chapter 3, on "Panopticism", concentrate on events that took place before and up to the mid-20 century, well before computerization and its impact on the web of spatial relationships across society. For example, Carmona et al. (1997) examine cost accounting and control practices in an $18^{\text {th }}$ century tobacco factory; Hoskin and Macve (1986) study the use of the examination (and other disciplinary techniques) from the medieval era until the $19^{\text {th }}$ century; Hoskin and Macve (1988) focus on the genesis of what they call "the new managerialism" in US businesses and factories in the $19^{\text {th }}$ century; Walker (2010) studies child accounting texts published in the US during the early to mid-20 ${ }^{\text {th }}$ century; Walsh and Stewart (1989) examine the link between accounting and the emergence of the factory in $18^{\text {th }}$ century Britain, etc. In line with Haggerty and Ericson (2000), what we do challenge is the pertinence of relying extensively on the panopticon metaphor or any of its derivatives, such as Poster's (1997) "super panopticon" or Gordon's (1987) "electronic panopticon", to make sense of and investigate contemporary surveillance mechanisms like those we describe in our case study where digitalization plays a key role.
} 


\section{Socio-ethnographic case study design}

Given that one of our initial research interests was the unveiling of novel forms of surveillance ensuing from the implementation of a KMS, a thick and rich description was targeted in order to make sense of what these new forms of surveillance might be and determine how they contrast with known, documented forms of surveillance. In-depth description aims to produce a "sense of déjà vu", which Langley (1999) argues is a typical outcome of good narrative strategies. The purpose is to provide readers with sufficient richness to assess the trustworthiness of the case (Lincoln \& Guba, 1985) and evaluate the extent to which the idiosyncratic processes uncovered by the researcher are comparable to others in distant times and spaces. We sought to avoid the threat of producing trivial theoretical developments or accounts of little interest to those outside the case firm by acknowledging these dangers right from the start and grounding our investigation in the surveillance literature.

The narrative research strategy is one with which ethnographers are familiar (Van Maanen, 1988). Beaud and Weber (1997, p. 10) argue that ethnographers have both a scientific and political vocation, "going against official visions of the world". Because of the interplay between these two vocations, Beaud and Weber $(1997$, p. 16) claim that researchers should be "personally and strongly involved in the field", and yet, that they should be able to reflexively analyze their own motivation and involvement. Such a value-bound enquiry approach is consistent with the naturalistic paradigm as described by Lincoln and Guba (1985, pp. 37-38).

The lead author of this manuscript worked for the case firm between 1999 and 2005 and experienced the roll out of the Parisian office's KMS, whose socio-behavioural effects are analyzed herein. Being aware that this prior involvement in the field might entail risks, including being enlisted by interviewees to adhere to their cause or the risk of entering the field being overly influenced by preconceived beliefs, three techniques were relied upon as antidotes: reflexivity, decentering, and self-analysis (Beaud \& Weber, 1997).

Reflexivity relates to the researcher's sensitivity regarding the quality of the data and how it was gathered. Key issues that were considered throughout data collection included making sure that the questions were neutrally framed without "inviting" any specific response or posing apparent judgment on the appropriateness of the KMS; and considering the most likely 
motivations of the interviewees in revealing what they know. Thoughts on these issues, which reflexively emerged during data collection, were systematically recorded in a research log.

Decentering relates to the maintenance of sufficient methodological distance from the situation being studied. Several roles or points of view were alternatively adopted in this respect, depending on the situation: (1) the point of view of an outsider, who knows very little about the firm and has nothing at stake in understanding whether the KMS might have "positive" or "negative" socio-behavioural effects; (2) the sympathizing point of view of a well-informed expert, who understands how frustrating and constraining systems can be for users; and (3) the point of view of a knowledge management consultant excited about the potentialities of KMSs. Despite their artificiality, we believe that these roles greatly helped in creating distance from preconceptions regarding the situation studied.

Self-analysis consists of reporting the researcher's own record of the phenomenon studied, almost as if s/he was interviewing herself/himself. Self-analysis was also facilitated through interacting with the second author, who was never a member of the case firm.

\section{The case firm: the Parisian tax and legal office of a Big Four public accounting firm}

The study was carried out in the Paris office (which we name herein FirmXLegalParis to preserve its anonymity) of the French tax and legal practice (FirmXLegalFrance) of a global firm providing a vast range of services in the areas of accounting, assurance, consulting and law (FirmXGlobal). ${ }^{5}$ FirmXLegalParis was selected because it was (reportedly) the first group of lawyers in France to adopt a centralized and formal KMS, and because one of the authors previously worked in the office. ${ }^{6}$ Moreover, FirmXLegalParis provided unconstrained access to almost any type of data concerning the usage of the system by the lawyers. Data collection was carried out from 2005 to 2008, but the scope of our study concerned the years from 1999, when the first version of FirmXLegalParis' KMS was implemented, to 2008, when its daily use by lawyers was relatively institutionalized. Implementation of the KMS reportedly took place in a

\footnotetext{
${ }^{5}$ FirmXLegalFrance is an independent legal entity, distinct from FirmXGlobal as far as its ownership structure is concerned. FirmXLegalFrance was affiliated with FirmXGlobal until 2003.

${ }^{6} \mathrm{KMSs}$ are generally designed to facilitate the process through which organizational knowledge is captured, codified, disseminated and reused within organizations (Gottschalk, 2005). The rhetoric of KMSs relayed in both the managerial and early academic literature promotes the idea that these technological devices can help enhance the quality of work. Recognizing the diversity of perspectives that can be mobilized in making sense of the notion of "knowledge", we define it for the sake of clarity as (input, process and/or output) information which can be used to provide professional services to corporate clients.
} 
general context characterized by intense competition among law firms, in a market for professional services where deregulation and free-market logic were celebrated. In a quest to rationalize their activities and processes at a time when knowledge management was the new managerial fad, some professional service firms were attempting to codify knowledge through cataloguing recurrent client issues, formalizing problem solving methods, and standardizing typical solutions to known problems:

"Within the information age, knowledge has become known as 'a strategic resource of social power and control' (Blackler et al., 1993, p. 851); and expertise 'one of the primary arenas in which struggles to control the organization and management of work are fought out' (Reed, 1996, p. 574).” (Dirsmith et al., 2005, p. 362)

Spreading knowledge for large-scale reuse within FirmXLegalParis was seen as a solution to help increase productivity, lower production costs, and strengthen formal control of work processes, in a context where FirmXLegalFrance was facing productivity and profitability issues:

In the long run, what is at stake with the deployment of our knowledge management system is quite simply the firm's survival. (Tax partner, July 2005)

\section{Collecting evidence: ethnographic observations, interviews and archival materials}

Data collection was structured along four distinct phases which, although sequential, partially overlapped. First, archival data was collected and analyzed in order to develop an indepth understanding of the local (FirmXLegalParis), national (FirmXLegalFrance) and global (FirmXGlobal) context in which the KMS was introduced and why. Archival data included FirmXLegalParis' internal documentation of the design, development, roll-out, and requests for enhancement of the KMS from 1999 to 2008, and knowledge management plans and activity reports from 1999 to 2008 (at Global, France and Paris level). Also, temporary access to the database used to compile the system's usage statistics was granted for a three-month period in 2005. In addition, we were provided with a survey conducted by FirmXLegalParis' knowledge manager in 1999 that aimed at grasping lawyers' fears and apprehensions concerning the imminent implementation of the KMS. The survey's report lists every interviewee (by name and hierarchical level) and provides extensive information on the content of the interviews. However, the report does not specify who made what comment (probably for the sake of protecting anonymity). We are, therefore, unable to attach a generic profile (e.g., partner, manager) to the excerpts from the survey that are incorporated in the paper. 
Second, seven preliminary interviews were conducted in 2005 with all of the partners who had been involved in supervising FirmXLegalParis' knowledge management activities since 1999. The objective was to refine our comprehension of the context in which the office had introduced the KMS and document key actors' understandings of how the KMS was accepted, used, resisted or circumvented by the lawyers. The interviewees' interpretations were contrasted and compared with the KMS statistics on daily use between February and April 2005 (17,861 documents were viewed or downloaded by lawyers over the three-month period).

Third, 51 additional semi-directed interviews were conducted mainly in 2006 (but up until 2008), ranging from 30 minutes to four hours, with 41 different informants (including four who were interviewed in step two). The aim was to investigate how the introduction of a KMS in FirmXLegalParis affected the social fabric of the organization. ${ }^{7}$ All interviews were one on one, taped (with the exception of three) and transcribed in extenso. Interviewees were selected based on their seniority level, industry and service specialization, with a goal of covering all areas of the firm's matrix structure - the belief being that lawyers with different profiles might use the KMS in different ways. We began each interview by asking the interviewee's permission to record the discussion, while ensuring complete anonymity of the data through the transcription process. Only one informant refused to be taped and two informants made changes to their interview transcript, thereby allowing us to identify politically sensitive issues associated with the KMS, including interpersonal conflicts. One of the main difficulties associated with the interviewing process was helping people to let go of their defence mechanisms when being asked to comment about the social effects of the KMS. As recommended by Baumard et al. (1999), we adopted an empathic and considerate attitude with the most defensive interviewees while attempting to extend the duration of the conversation as much as possible in order to allow the interviewees to be reassured of our intentions. For instance, one senior manager who was openly hostile towards the adoption of the KMS allowed us to spend two sessions of about four hours each during which her attitude turned from mocking and suspicious to transparency - to the point where tears were shed and confidences were shared. All interviews were in French; we translated the excerpts incorporated in this paper.

\footnotetext{
${ }^{7}$ The questions asked to the interviewees included, but were not restricted to: What do you think is the influence of the KMS on how you write legal and tax opinion letters; on how you search for expertise; on how you interact with peers; on how work is organized and delegated in the engagement team? Do you believe that using the KMS has influenced the way in which self-constituted groups of experts are being formed and disbanded in FirmXLegalParis? Overall, would you say that the KMS has had a rather positive, negative or neutral effect on your work environment?
} 
Fourth, five meetings were attended; two organized by the tax line of service devoted to mergers and acquisitions; two by the line of business devoted to the pharmaceutical industry; and one by an ad-hoc group ("research and development tax credit group"). Discussions centred on technical issues of law arising from on-going client engagements, and the selection of bestpractice tax and legal opinion letters to be uploaded into the KMS.

The results of the study were presented to FirmXLegalParis' managing partner four times between 2006 and 2008 during non-recorded meetings of approximately two hours each, in order to obtain her/his viewpoint on the plausibility of the case interpretations. After having initially challenged the interpretation that the KMS was used as a control device, s/he later recognized that lawyers mistakenly believe that the KMS is being used to inspect their opinion letters.

\section{Data analysis}

We analyzed the data by searching for central "stories, meanings and mechanisms" (Langley, 1999, p. 696). We gradually made sense of the data by mapping them onto conceptual categories of abstractions. We used QSR NVivo to construct taxonomies of codes emanating from the field (inductive approach) and from a literature review (deductive approach). This systematic iterative process of comparison between field data and theoretical anchors was also fuelled by inferences drawn from our own inspirations (Weick, 1989) and judgment, which were useful in elaborating a sense of the "latent content" of the data (Berg, 1989).

The data analysis process started with intuitive inferences made during the first two phases of the data collection process. When we moved to phases three and four, during which extant research on accounting and managerial controls was frequently consulted, we iteratively mapped our initial "in vivo" codes onto an organized tree of codes. These codes stabilized once the point of "theoretical saturation" was reached (Glaser \& Strauss, 1967). In the process, preponderant themes and arguments were identified. Overall, we believe that our analysis allowed us to go beyond apparent logics and uncover the deeper meanings underlying interviewees' views on the social transformations ensuing from the use of the KMS in FirmXLegalParis. ${ }^{8}$

\footnotetext{
${ }^{8}$ We assume that the technology (a KMS in our case study) and the social (users of the technology) are not only mutually shaping each other but are, in many aspects, mutually constitutive of each other. The notion of Best Practice, for instance, emanates from the very users of the KMS, yet the Best Practice indicator is also a feature of the KMS, which influences the types of documents that users tend to download. We therefore avoid talking about the social impact of technology, since it entails a deterministic stance that we do not support. However, words are tricky.
} 


\section{Ramifications of surveillance ensuing from the KMS}

The understanding of what surveillance is can be addressed legitimately by examining how digitalized technologies of surveillance play out in the everyday lives of agents and targets of surveillance (Gilliom, 2006). Accordingly, we focus on the patterns of experience, language, and action that construct the actors' consciousness of KMS surveillance. Our field observations are organized in a three-step process. First, we describe the local, regional and global organizational context surrounding the adoption of the KMS in FirmXLegalParis. Next, we provide a sense of the surveillance practices at FirmXLegalParis prior to the introduction of the KMS. Finally, we examine how complicated flows of surveillance ramified from the adoption of the KMS.

\section{Organizational context}

As briefly mentioned in the method section, the adoption of a KMS was seen as a means to enhance FirmXLegalFrance's economics. The Parisian office was designated as the first office to implement one. Although a deployment of the system to the other offices in France had been envisaged, this never took place, therefore making what was meant to be FirmXLegalFrance's KMS, de facto, FirmXLegalParis' KMS.

In early 1999, FirmXGlobal had just rolled out a cross-national and cross-discipline (tax, legal, consultancy and audit) KMS (called PlanetKnowledge) but it was typically considered, within the firm, as an empty shell. The leitmotiv of FirmXGlobal's newly promoted Chief Knowledge Officer (CKO), at that time, was that every employee of FirmXGlobal should be able to access all the "knowledge" of the entire organization in one click:

PlanetKnowledge is the firm's number one priority. It is intended to become a single, dynamic, universally accessible knowledge environment that leverages the intellectual capital of everyone in FirmXGlobal. (1999 issue of the internal newsletter devoted to knowledge management within FirmXGlobal)

The "fantastic" cross-selling opportunities that the global KMS would generate were repeatedly emphasized by the $\mathrm{CKO}$, in trying to encourage local practices to upload content into

When we speak of "technology", we really mean "socio-technical assemblages" or "socio-technical entanglements" in the sense of Orlikowski (2007) - but it would have been cumbersome to use these periphrases instead of the word "technology" or "KMS" in the article. 
PlanetKnowledge. Yet some of the most influential local practices in FirmXGlobal (including the US and UK tax practices, shortly followed by the German tax practice as well as the Dutch tax and legal practice) argued that they were already using their own local and discipline-specific KMSs; as a result it would be redundant to contribute to the global multidisciplinary KMS. ${ }^{9}$ As the debate gained momentum, the managing partner of FirmXLegalParis rallied to a movement initiated by the Dutch tax and legal practice and, as a result, developed a customized version of the Dutch system for use in the Paris office. The global KMS never really took off and this resulted in the CKO leaving the organization in 2000. Less than two years later, however, almost all of the "dissident" local practices (including FirmXLegalParis) had partially interfaced their respective KMSs with the global system, but remained in control of what local content could be seen from abroad. Despite numerous attempts from the global headquarters to convince them, in the name of harmonization and cost effectiveness, to switch to PlanetKnowledge, every local practice kept its legacy system.

The ergonomics and technical architecture of FirmXLegalParis' KMS constantly evolved during our study, but its basic (and stable) functionality consists of a database of selected legal and tax opinion letters, and a search engine allowing users to sort content by technical key words (e.g., "withholding tax rate", "parent-subsidiary regime", "double-dip taxation"). Content can be viewed by author, date or client name. The database can also be browsed by industry (e.g., distribution, oil and gas) and key areas of business and tax law (e.g., research tax credit, intellectual property law). The system incorporates various categories of documents, most of which are internally produced by FirmXLegalParis' lawyers during the course of their various engagements (e.g., contracts, opinion letters, memos, presentations, reports, methodological toolkits, due diligence checklists).

It is interesting to note that knowledge management committee members, who are rotationally appointed to this position for a fixed period of time, have met continuously on a monthly basis to review all new content added to the database and award a "Best Practice" label to documents they judge particularly well-written and useful to reuse by all. Pieces of content considered as technically erroneous or poorly written are systematically archived in a specific

\footnotetext{
${ }^{9}$ The local audit practices did not participate to the debate since none had a local legacy KMS in 1999. Many local consulting practices had their own KMS but did not participate to the debate since the largest local consulting practices were then in the process of separating from the global network.
} 
area of the database which is not searchable by regular users. The knowledge management committee was originally created in 2000 to flag best practice opinion letters and identify outdated and faulty content on the KMS. The committee initially comprised one partner, as chair, and ten rotationally appointed lawyers with seniority levels ranging from junior to senior manager. The idea was that everyone in the firm should, sooner or later, sit on the committee. The committee eventually diversified into several sub-committees, each focusing on a specific line of service and chaired by a distinct partner. At the time when we conducted most of our interviews, the knowledge management committee had not yet been broken down into sub-units.

The committee's review process is typically perceived by lawyers as a new formal quality control mechanism and is criticized heavily by some for being partial, subjective, and an opportunity for the members of the knowledge committee to award "Best Practice" labels to their own work:

Interviewee: He [i.e., partner chairing the knowledge management committee at the time of the interview] chooses the "best practices". If you examine the authors of those best practices, [...] you will realize that I wrote only one. [...] If you download all of the best practices, you'll find out that about $80 \%$ of them are in fact signed by [partner chairing the knowledge management committee].

Researcher: You mean that this is a self-awarding process?

Interviewee: Yes. (Senior manager, October 2006)

FirmXLegalParis' KMS exemplifies what Foucault refers to as dividing practices, predicated on the ranking of documented cases in the database. The governance of a population indeed requires an analytic framework by which the targets of control can be ordered (Townley, 1994). What is perhaps the most noticeable in the above excerpt is the interviewee's ironic tone against the authoritative party which decides on the ranking. Rankings are not seen as ensuing from Nature but are understood clearly as resulting from a politically-informed process. This contrasts with the claim made by Lyon $(2001$, p. 7) that "few people feel constrained, let alone controlled, by surveillance regimes". We observed, on the contrary, that the constraining dimension of the establishment of a list of best practice opinion letters did not pass unnoticed:

Selecting best practices is a means to constrain people's creativity. It means that we are going to reward only one solution to a given matter of law. (Anonymous interview comment excerpted from: Report of the survey - Knowledge Management Project FirmXLegalParis, 21 July 1999, p. 17, our translation) 
Following Foucault (2003), it can be argued that particular discourses, which delineate the boundaries of what can be said about something, encourage the construction of particular conceptions of normality and abnormality. In the context of FirmXLegalParis, some lawyers feared that the sanctification of "best practices" as the only official and legitimate discourse on every matter of law, might produce at least three different classes of subjects: those who produce best practices, those who re-use them, and those who produce tax and legal opinion letters that are inconsistent with the best practices and can always be declared deviants. The hierarchy between these various types of subjects is not clear-cut, however. On the one hand, lawyers who produce new tax optimization strategies, for instance, can be thought of as belonging to a superior class than journeypersons, who simply re-use and sell codified knowledge. On the other hand, and as endorsed by the majority of interviewees, recycling may translate into a strengthening of one's commercial performance and productivity. The latter scenario is consistent with Brint's (1994, p. 204) argument that when professional knowledge "comes to be seen more strictly as a marketable resource", it is more likely to be "treated in a more purely commercial vein". Indeed:

This system will be frustrating for the specialist. His knowledge will be put at the disposal of everyone in the firm and he will have no credit for that. Besides, creators will be less recognized than vendors of knowledge, even if the latter are able to sell technical solutions without having contributed to their elaboration. (Anonymous interview comments excerpted from: Report of the survey - Knowledge Management Project-FirmXLegalParis, 21 July 1999, p. 26, our translation)

The majority of our interviews indicated that the ways of thinking and doing surrounding the KMS encouraged unbridled appropriation, in which one can creatively use and modify the content of best practices to fit one's own purposes.

Surveillance prior to the introduction of the KMS: an emphasis on clan controls

Interviewees mentioned that, before the KMS was introduced in 1999, organizational control over work consisted mostly of clan-based controls, complemented with a few administrative controls. The clan controls were predicated on an internal labour market philosophy, focused on the selection of the lawyers "best suited" to the working environment, with gradual elimination of the "least suited" ones. The emphasis on clan controls is consistent with past research documenting the traditional prevalence of social controls in professional service firms (Grey, 1998; Lazega, 2001): 
Interviewee: I have always worked the same way, I mean, the word "friendship" might not be the best word but I have always worked with people I liked, with whom I had a good feeling.

Researcher: Have you always worked with the same people?

Interviewee: Always with the same, yes. [...] It is more difficult to manage, because you have these affective links to deal with, so it is more difficult, but more interesting as well. I have always been convinced that affective links are useful to defend my people, to help them progress faster. [...] Those who have worked with me have never complained. (Tax partner, July 1999)

The administrative controls consisted primarily of management by objective techniques, as explained by FirmXLegalParis' financial officer:

We motivate people via what we call the "standard input". A person's standard input corresponds to what this person is supposed to sell depending on her/his level of seniority. (Financial Officer, March 2006)

The corollary of a person's "standard input" (in euros) is a volume indicator (in hours), used both for target setting and performance evaluation - the "hours charged". This indicator is primarily used for junior lawyers and has a translation for senior lawyers - hours billed and managed. These indicators are claimed to reflect one's quality of work:

The demand for rigor in our professional world is [important]. [...] The sense of rigor must be inculcated very early in one's career. You have to work with rigorous and demanding people early on. [...] And there is an objective performance measure for the partners: the revenue that they personally generate. I was trained by [name of individual 1] and [name of individual 2]. They taught me to be very self-disciplined and I really had to move my ass. For young professionals, the only valid performance indicator is their number of chargeable hours. But the system is vicious. You have to start things the right way, otherwise... (Tax partner, June 2006)

Nonetheless, our analysis indicates that cultural and clan-based controls constituted the foundation of FirmXLegalParis' control philosophy. As vaguely implied in the last sentence of the above quotation, work was organized organically, with important pressures being observable in the quasi-spontaneous formation of small teams of professionals choosing to work with one another based on interpersonal preferences and a shared vision of the world:

It takes affection for a team to work well and be successful. [...] Chemistry is the key word. You need to like people and think highly of them. [...] In my group, we understand one another, culturally, I mean. (Tax partner, June 2006) 
Those lawyers who do not manage to become accepted in one of these organic, unplanned sub-organizational units find themselves isolated and eventually leave the organization, most of the time on their own initiative:

Interviewee: We are very stressed out. We have impossible deadlines, always extra things to do that we did not anticipate. [...] So yes, eventually, we always end up working with the same people because our job is very difficult. We already have enough difficulties. Why would you want to create more problems, by working with someone whom you expect to perform shoddy work?

Researcher: How do you know that someone you don't usually work with is going to do a bad job? By word of mouth?

Interviewee: Of course.

Researcher: How does this work exactly? Is it reliable?

Interviewee: Pretty reliable, yes. [...] Those who are not good, at one point, people stop giving them work. And if you are not stupid, when you don't have any work to do for a long period of time, when you don't charge any hour, then you pack your stuff and find a job elsewhere. (Tax senior manager, May 2006)

As the above quote suggests, informal control mechanisms (accepting or rejecting certain individuals based on interpersonal preferences in self-constituted social niches) and management by objective techniques (standard input, chargeable hour targets) may reinforce one another. When a staff member does not belong to any social niche, s/he cannot "charge hours". The copresence of clan-based and administrative controls is not new in bureaucratized professional service firms; the situation that we observed at FirmXLegalParis prior to the introduction of the KMS is not different from situations already documented, notably by Dirsmith, Heian, and Covaleski (1997) in large accounting firms.

In sum, prior to the introduction of the KMS at FirmXLegalParis, the disciplinary process was mainly informal, collegial and self-centered. Peer pressures to perform (i.e., being technically rigorous and hard working) and to conform (i.e., joining one or several existing "social niches", to borrow Lazega's (2001) expression) were emphasized in the office's daily undertakings. For someone who failed to behave in accordance with those pressures or who resisted them, the social rejection process was such that lawyers with a poor internal reputation or who did not belong to any social niche often felt compelled to leave FirmXLegalParis. Formal coercion was minimal and only an embryonic form of administrative control existed, which manifested itself through the authority of a single performance indicator - hours charged/billed. The main control philosophy that was then used in the office was largely informal and clan- 
based. Networks of surveillance operated accordingly - that is to say organically. Although individuals could rely on impression management in trying to present an appealing image in front of their peers, day-to-day interactions among team members allowed every member to observe how the other members "really" behaved. Reputations beyond one's working group were haphazardly conveyed through word-of-mouth.

Overall, control within FirmXLegalParis prior to KMS is not significantly reflective of hierarchical, panoptical monitoring. The introduction of the KMS destabilized the office's ways of doing things regarding control of work and had the potential to make it more consistent with panoptism. Yet the introduction of the KMS and its underlying control philosophy does not imply disappearance of the former control mechanisms, as the following quote illustrates:

For managers, you know, networking is paramount. [...] You have to go out for drinks with people. I say "have to" because it is very difficult to do. You have to be nice, make yourself known [...] because if you have to run after a partner... I mean, if you wait for a partner to come to you, it is always an incredible loss of time, and it helps to be able to ask for other people's help - other managers I mean. These "little friends" so to speak, in fact "friends" might be a bit too much, but these informal relations are tremendously helpful. [...] It's very important to have your own little social network that you can rely on. (Tax senior manager, May 2006)

It therefore seems that through the KMS an additional layer was incorporated to the net of controls within the office, which we discuss in the next sub-section.

Surveillance once KMS is implemented: seeing, showing off and being seen

Shortly before the implementation of the first version of FirmXLegalParis' local KMS, a survey was conducted internally in the office (July 1999) to assess future users' expectations and concerns. The survey, conducted by the office's knowledge manager, was based on interviews with 16 partners, ten managers and senior managers, and six junior lawyers, representing about half of the lawyers working in the Paris office at the time. As illustrated in the two excerpts below, reactions towards the imminent implementation of the KMS include scepticism regarding the real purpose of the system, doubt regarding the expectation that everyone will contribute knowledge to the database, and even the fear of professional autonomy being threatened:

The introduction of best practices will create an intellectual orthodoxy. Is this really what we want?

Does it mean that we are going to create a quality control committee? How will this work? Who will be part of it? What will be its prerogatives? I'd be curious to see how 
this will work. Besides, there is a big patrimonial risk here. All our knowledge can be robbed in a simple click.

(Anonymous interview comments excerpted from: Report of the survey - Knowledge Management Project - FirmXLegalParis, 21 July 1999, p. 27, our translation)

These reactions suggest that the rationalizing and controlling potential of the KMS did not pass unnoticed, even though the office managing partner frequently specified that the system would primarily serve to enhance the quality of service.

The first version of the KMS consisted of a large database accessible to all, a search engine, and a workflow system. The workflow system went along with a number of organizational changes. First, all partners' secretaries at FirmXLegalParis were asked to upload the last version of the output of every client engagement in the KMS. Not all partners abided by this rule, however. One partner, in particular, who refused to be interviewed, was known by most people in the office for being against the idea of sharing knowledge through the KMS. His secretary pointed out that she refrains from uploading his documents in the system for fear of potential consequences. When we questioned the office managing partner on the matter, he pointed out that peer pressure is more effective than any sanction he might apply:

Researcher: Who are the secretaries loyal to? To their partner or to you, when you ask them to upload documents in the database?

Interviewee: I never put them in a situation where they have to choose. So when there is a problem, they make me aware of it. However, I don't want secretaries to solve the problem on my behalf. I get the database usage statistics you know. But I prefer to manage things carefully, through discussions with the industry lines' leaders, the service lines' leaders, the focus groups, etc. I never do anything directly. (Office managing partner, August 2007)

Once uploaded, the content was then indexed with an extensive number of meta-tags including the name of the partner in charge of the project, the author of the document (generally the manager in charge of the project), a description of the technical issue addressed, relevant key words, the document's date and type, the name of the client for which it had been prepared, etc. Also, the approximate production cost of the document had to be filled in, based on the number of hours that the authors had spent on it. When being asked why cost information mattered, the office managing partner answered that it was meant to prevent users of the KMS from re-using a document (e.g., an opinion letter or a contract) without knowing its original cost. In other words, 
if a document was to be downloaded from the KMS and re-used, it was expected that its original cost would be taken into account in the billing of the client.

The secretary who had uploaded the document and pre-filled the above template then had to print another template (called "knowledge card", internally) and get the partner in charge to review and sign it. The case document was then made visible to all in the KMS and thus could be retrieved by any user who would search for it.

Finally, the printed and approved knowledge card was added to the client file. Quality control peer reviews were conducted once a year and included a comprehensiveness check, to ensure that every client file matched with at least one knowledge card. The office managing partner was notified of the deviant files. Based on our observations, no rigorous sanction actually followed, apart from verbal reprimands.

These arrangements remained practically unchanged over the entire period of observation (1999-2008). One important change, however, was the distinction between archive management and knowledge management having been clarified over time, with all documents older than one year being automatically moved to a section of the KMS server called "archives" (only searchable by a few administrators), whereas recent and best practice documents, including best practices older than one year, remained searchable by all. The second most important change was the knowledge committee having been progressively split into a variety of specialized knowledge committees, mirroring the firm's matrix structure. By 2008, the KMS contained about 20,000 documents, and was used every day by most rank-and-file lawyers.

Drawing on Foucault's ideas, we argue that the KMS new control apparatus establishes an analytic grid by which certain details of engagements and their contributors are rendered visible. Through legal cases being formally documented a form of normalization is emerging, in which the most popular or institutionally favoured cases set the benchmark for future work and for defining abnormalities. Further, via the KMS, individuals can be constructed as objects, whose performance is manageable from a distance by administrative partners. A new disciplinary gaze, largely reflective of hierarchical panopticism, is suddenly upon the shoulders of the office lawyers, at least in principle. Yet with the benefit of privacy, any lawyer within the firm has electronic access to the details of documented cases and therefore can assess the quality of the 
work and the performance of the lawyer who did it. Conditions are, therefore, in place for a significant alteration of the way in which lawyers and their work are controlled within the firm.

When being interviewed on the extent to which the office's administrative controls had changed as a result of the implementation of the KMS, a number of participants mentioned that changes are relatively minor, despite the increasing use of new qualitative performance indicators. Charged and billed hours remain preponderant in determining lawyers' bonuses. However, many lawyers are convinced that the KMS is hierarchically used by the office managing partner to control their work, as the following two excerpts suggest:

[The office managing partner] went through the knowledgebase to check the liability cap clause [in one of my due diligence reports], the other day, and did not find the report. So I got told off! And for once, he [the office managing partner] was right. ${ }^{10}$ (Tax partner, June 2006)

Researcher: You mentioned earlier that the main problem with the knowledgebase is the uncertainty regarding the quality of its content.

Interviewee: Yes but that's because it is tightly managed by [name of the managing partner of FirmXLegalParis], and also because it is linked to our remuneration system. ${ }^{11}$ (Tax senior manager, November 2006)

Several interviewees were also quite critical of the basic objective which apparently underlies the deployment of the KMS within the firm. For instance:

Researcher: I would like to know your thoughts on the underlying purpose of the system, when it was created back in 1999. What was the strategy behind all of this, in your opinion?

Interviewee: What I think... the industrialization of legal advice. That's what I think. Researcher: What for?

\footnotetext{
${ }^{10}$ In this discussion, the interviewee refers to an internal document called "Manuel de prévention des risques professionnels", released shortly after FirmXLegalFrance spun off from FirmXGlobal in 2003 in the aftermath of the Enron scandal. The document includes (p. 25) a section called "liability cap clauses" which requires every engagement letter to comprise a clause specifying a contractual limit (in euros) regarding the level of responsibility assumed by the firm. Specifically, responsibility is limited to "the higher of the following two amounts: 305,000 euros or the total gross fees charged." For this clause to be enforceable, lawyers have to obtain its formal ratification by clients.

${ }^{11}$ Linkages between knowledge management objectives and compensation were established in the office two years after the introduction of the KMS. Objectives included, among other things, the development of new intangible assets (e.g., new tax optimization strategies), and the overseeing of a sub-knowledge management committee. The extent to which every partner met her/his KMS objectives was subjectively assessed by the three members of FirmXLegalParis' Management Committee, on a yearly basis. The maximum bonus to be gained from reaching knowledge management objectives represented $25 \%$ of the total bonus that partners could potentially obtain by reaching their traditional financial targets, measured in terms of fees invoiced and fees managed. A partner's total bonus could represent up to $60 \%$ of the fixed component of her/his remuneration.
} 
Interviewee: To increase margins and growth. (Partner, June 2006)

However, we found significant variability in interviewees' standpoint regarding the pertinence of the KMS. The following excerpt provides a positive view on the matter:

Researcher: In your opinion, what is the purpose of the KMS?

Interviewee: I see two reasons. One, to avoid reinventing the wheel. Two, for security reasons. I mean, to make sure we don't miss anything important. Hence the importance of checking what the others have written on similar issues, especially when their opinions are identified as "best practice" by the knowledge committee.

Researcher: And how do you feel the firm is currently doing on this?

Interviewee: Regarding control, we've made considerable progress. (Director, June 2006)

Perhaps unsurprisingly, the office managing partner denies invasive scrutiny of KMS documents, being amused by what he views as a "Big Brother fantasy":

Researcher: Do you use the KMS for quality control? Do you check who writes what in his or her area of specialty, for instance?

Interviewee, smiling: No. I don't have time for that [...]. Besides, right now, the KMS cannot be used as a control tool because we are still in a phase where we want to stabilize adoption and avoid discouraging people from contributing new content. (Office managing partner, August 2007)

However, as articulated through the panopticon concept, control fantasies (such as lawyers' potentially false perception that the KMS is used by the office managing partner to control their work) can be powerful at engendering a climate of suspicion, which can be instrumental in rendering the targets of control docile and compliant. Is our interview evidence in line with the classic imagery of panoptical control? On the one hand, administrative control does not appear to have been radically transformed as a result of the implementation of the KMS. Yet, it encouraged the development of new ways of thinking and doing, regarding control of work, to the point that we argue that the office's culture of control, originally predicated on the clan control philosophy, has been substantially transformed - but far from being uniquely reflective of the panoptical metaphor and the regime of anxiety it is supposed to engender.

While the KMS allows hierarchical surveillance (at least in theory), our interviews indicate that one of the main ramifications ensuing from its implementation is the development of a form of lateral surveillance. Specifically, the KMS technology is diverted by rank-and-file lawyers to serve new games of power and visibility among themselves. The KMS is, therefore, characterized 
with enabling capacities in the sense that most lawyers come to enjoy the web of visibility it engenders. The games of power we uncovered are consistent with Lazega's (2001) observation that: a) professionals politicize their exchanges of scarce resources; and b) work relationships among peers are not necessarily congenial and nice nor synonymous of "mechanical solidarity", even in collegial organizations. One of the most intriguing aspects emerging from our case analysis, however, is that, through the implementation of a hierarchical mechanism of control, the rhizomatic surveillance (Haggerty \& Ericson, 2000) really throve within the office.

By making legal and tax opinion letters visible to everyone, the KMS gives rise to lateral pressure on the technical quality of work outside of line relationships. Who is a star? Who is an amateur? Who prepares opinion letters within her/his area of expertise, and who "poaches" on other people's domain of expertise? The impact of this lateral pressure is double-edged; not only does it increase internal demand on the quality of outputs, but it also stirs up interpersonal tensions:

Researcher: Have you ever detected any error in some of the documents stored in the knowledgebase?

Interviewee: Yes. But I am very indulgent on this because we all write bloody stupid things sometimes. No matter how many layers of quality controls are established, there will always be some errors. I even found errors made by [name of tax partner famous for his expertise] on the database. And he pretends to be infallible! [...] But what I don't understand is why people get upset when I come to see them and say: "You wrote this and I don't agree with you."

Researcher: Did this really happen?

Interviewee: Yes, although I did it tactfully, you know! I said: "I don't think that this is right but perhaps I did not understand you well." The problem is that the person was displeased. Very irritated, in fact. Quite frankly, what I think is that we all make errors but we should not let errors stay in the knowledgebase. (Tax partner, April 2006)

These observations substantiate Dirsmith et al.'s (2005, p. 362) point that "the encoding of expertise within expert systems is likely to be fraught with conflict" and "the process of using expert systems may [...] socially reconstitute the very meaning of expertise." Before the introduction of the KMS, individual expertise was constructed on reputation from cues on the lawyer's quality of work as team member in a chronology of engagements. Now, expertise is more in line with the notion of performance constructed through the examination of visible outputs recorded in the database. While visibility surrounding one's work was formerly 
restrained to a small group of people (one's team), it expands considerably in scope with the introduction of the KMS being available to all. While reputational cues of expertise are still influential, our analysis indicates that expertise is now mostly perceived and enacted as a visibility matter, predicated on the production of flawless opinion letters, whose irreproachableness is somehow verifiable by KMS users.

Our analysis, therefore, indicates that the KMS control template exerts significant influence through lateral visualizing on the network of social relationships within the office. Surveillance clearly intensified as a result of the "knowledge" that the KMS provides to administrative partners (at least in theory) in managing people and their performance, and to rank-and-file lawyers in being aware of their peers' work and performance. As mentioned above, lawyers tend to believe that the KMS is or might be used by the office managing partner in controlling the quality of their work. Whether this is pure fantasy of Orwellian control, as the previous comment from the office managing partner implies, or reality, it does not make any difference. In the end, it is the possibility of being watched - either by administrative partners or peer lawyers - that leads lawyers to modify their behaviour. Many reportedly feel compelled to increase the quality of their work made visible in the database. Just in case. This self-disciplinary process occurs without any sanction or reward mechanism, but through the "fear" or possibility of being seen as a bad lawyer. Is the KMS just another illustration of the traditional panoptical control device described by Foucault and many others after him?

In addition to the potential gaze of the office managing partner in watching subordinates, a constellation of watching gazes is provided by rank-and-file lawyers, who do not only behave as targets of surveillance but are also actively involved as agents of surveillance. In so doing, these agents, wittingly or not, participate rather than resist in the ramifications of surveillance ensuing from the introduction of the KMS. Any person within the organization can see the work done by others (as long as it is uploaded) because of the new visibility offered by the KMS. It is as if "prisoners", to follow on the panoptical imagery, were watching and monitoring one another. In itself, the KMS has no intrinsic substance or social effect. The new surveillance system takes on meaning only through the ongoing and complicated interactions between users and the technology. While the KMS incorporates, through its design, a particular structure of domination, legitimization and signification (DeSanctis \& Poole, 1994), these latent structures cannot be enacted in the office without the agency of users. In our case, agency translates into complex 
games of visibility characterized with shifting and unstable boundaries between the front stage and the backstage, and the use of impression management techniques (Goffman, 1959).

According to our analysis, the awareness of lateral surveillance as fostered by the KMS-inuse fuels the development of a number of unofficial networks of documentation and dissemination of knowledge, which can be seen as informal markets of knowledge, outside the scope of the central KMS. These informal markets allow individuals to avoid "being seen" by unknown and unapproved others. The unofficial structures of the knowledge depository harbour opinion letters within specific social niches, whereby individuals decide to make their work visible but only to a small group of chosen individuals. Accordingly:

Researcher: Do you download and reuse documents that others render available through the KMS?

Interviewee: It depends on who wrote what. I mean yes I use it all the time. When I am stuck on a technical problem, I browse through the database to check if somebody might have already written something on that problem. For instance last week, I had an issue regarding business license tax. And I found that [name of tax partner 1] had already written something on the same problem, and I totally shared his opinion. So I went to see him, to talk about it. But the limitation of the KMS is that some people don't upload all of their opinion letters. So you cannot find everything.

Researcher: Why is that, do you think?

Interviewee: I think that it is primarily because of antagonisms in the firm. If one partner generates revenues of four million euros and all the others generate only one million, it's kind of unfair for the former because the office's profitability will be bad as a result of the lack of productivity of the others. [...] We are fed up with partners who stopped being productive many years ago. I mean, people like [name of tax partner 2] and [name of tax partner 3], we don't want to share any information with them.

Researcher: So who wouldn't you mind showing your opinion letters to, instead?

Interviewee: People I trust. (Senior manager, February 2006)

Hence the KMS did not translate into a transparent and democratic arena where all reports and documents produced by the office's lawyers could be seen by their peers. Pockets of knowledge traditionally controlled by small informal sub-organizational units remain. Despite the managerial injunction to upload all outputs into the knowledgebase, we found that several lawyers refrain from sharing their opinion letters with the other members of the organization. Instead, they created unofficial markets of knowledge where documents are distributed outside of the central KMS, among select individuals chosen on the basis of individual preferences, as the 
following discussion between three lawyers illustrates. The topic they discuss relates to a document that the partner wanted to share initially via the KMS. The director and the manager, however, believe that the document should not be disseminated too widely; they would rather upload it in a secured server, accessible only to people within their line of services:

So, is this in the knowledgebase yet? (Tax Partner)

Well, right now I only have it on paper. (Tax Director)

It would be good to put it in the knowledgebase, and then, to tell us where we can find it because... [smile and look meaning that it is hard to precisely locate things in the knowledgebase]. (Tax Partner)

And what about our own secured database? Where are we on this? (Tax Manager)

Don't worry, it will come. For now, we are not allowed to have our own knowledgebase [i.e., organized along each partner's line of services]. Don't ask me why, I have given up trying to figure out why. (Tax Partner)

OK, well I guess I'll upload it when we get our own secured server space then. Do you want a photocopy? (Tax Manager, May 2006)

This situation resonates with another one described by Hopwood (1973), where managers issued an official budget for motivational reasons but kept a secret one (in their "bottom drawer" so to speak) more in line with what they thought was more likely to occur. One can wonder what would have happened if the unofficial budget had been discovered by those who were bound by the official one. In the case of FirmXLegalParis, the existence of unofficial markets of knowledge was known or suspected by most, yet it did not prevent usage and growth of the official central market of knowledge (i.e., the KMS):

Interviewee: Everybody knows that some people don't put all their work in the database.

Researcher: Is this something you have found in your group?

Interviewee: No, but that's because my group is formally authorized to write VAT [Value Added Tax] opinion letters. However, people who do not belong to our group nevertheless do VAT consultations. And they don't upload their documents to avoid us of accusing them of doing it.

Researcher: Is this phenomenon proved to be happening or is this only a suspicion that you have?

Interviewee: No, it's real. One day, a manager with whom I was working told me: "Don't bother looking for it (i.e., an opinion). You won't find it in the knowledgebase. I'll send it to you."

Researcher: Was this someone from the VAT group? 
Interviewee: No. (Senior Staff, April 2006)

Not only do a number of niche experts keep "bottom drawer knowledge" for their groups, but so do lawyers who work on domains of law outside of their official area of specialty. ${ }^{12}$ Interestingly, when the knowledge directory initiative emerged in 2000, almost concomitantly with the creation of the KMS, it was heavily resisted and criticized by most lawyers in FirmXLegalParis on the grounds that it was the emanation of a bureaucratic mind and a limitation of one's professional freedom, having to specify in advance the domains of law in which s/he had to be involved. Paradoxically, despite the assurance given by FirmXLegalParis' managing partner that this taxonomy of expertise was not going to be binding, we see lawyers legitimizing the taxonomy through the ramifications of the KMS, via finger pointing at “deviants" that poach on other people's official domains of expertise inappropriately.

Others, on the contrary, do not avoid being seen and are proactive in their uploading of documents into the KMS. For them, "being seen", a passive and anxiety-provoking process, becomes "showing off", an active process through which the targets of control purposively seek to draw the attention of unknown agents of surveillance:

The window of opportunity is very short once the annual general meetings are done. [...] This means that we still have about ten days to sell this product while it's still "fresh". Afterwards, it will be out-of-date. So I have just written a note on the knowledgebase. Tonight we have a partners' meeting and I'm going to tell them, "I have a promising idea, it's sellable but it has to be sold 'asap'. So go ahead guys, it's the right time to sell it." (Legal partner, March 2006)

In so doing these lawyers, perhaps unintentionally, legitimize the KMS while contributing to the spread of surveillance. Whereas the panopticon was meant to automate discipline and bring about self-monitoring in prisoners while rendering the physical presence of watchers all but redundant, in the situation that we describe here, the watchers' involvement is indispensable

\footnotetext{
${ }^{12}$ FirmXLegalParis's commercial leaflet includes a list of experts that clients can contact for each line of service. In a similar vein, FirmXGlobal's intranet includes a so called "knowledge directory", which lists the local experts per line of service (e.g., indirect tax; intellectual property law, etc.). The two listings match each other and are updated simultaneously. The point is that some lawyers, for instance, reportedly do indirect tax consultations once in a while to boost their annual chargeable hours indicator, even when they are not officially referenced as experts in indirect tax. When this occurs, lawyers tend to keep their opinion letters away from the central KMS to avoid being caught trespassing on someone else's "intellectual property".
} 
because "prisoners" are playing games of visibility precisely to draw the watchers' attention and obtain positive feedback as a result:

Interviewee: For now, we have uploaded a certain number of fact sheets into the KMS and have described how our team operates. [...]

Researcher: So, tell me if I am wrong, but what you're doing is like sending a signal saying: "here we are and here's what we can do on research tax credits".

Interviewee: Exactly. It's like the presentation of a new line of service so to speak. (Senior manager, March 2006)

Interviewee: Now I see the database as a portal, like a forum of competencies. [...] So I often tell my people, "put this on the portal".

Researcher: Why is the portal important for your group?

Interviewee: I think it's very important, although I might not be the best person to ask because I rarely use the database. But sometimes I come across an opinion, a decision or something else and I think: "We must put that into the portal. It will be good for the visibility of our team." (Partner, leader of the "International Banking” group, April 2006)

Impression management (Goffman, 1959), therefore, intermingles with surveillance, resulting in a very complex array of social forces impinging on subjectivities and human relations. The normalizing agenda underlying the KMS is deviated from its trajectory by the agency of actors seeking to manage their visibility in their working environment. While voluntary self-disclosure generally takes place in relations of interpersonal trust (Lyon, 2001), in FirmXLegalParis the notion of interpersonal trust does not really apply because those who watch are unknown, and thus unapproved, by the actors. Yet voluntary self-disclosure does take place. The interactive possibilities offered through the digitalization of the KMS engender games of visibility which significantly influence disciplinary and self-disciplinary power in the office under study.

In sum, the introduction of the KMS within the office added another layer of control on lawyers that ramified in complex ways. Significant changes, most of them difficult to anticipate, resulted from the bureaucratization of knowledge sharing. In spite of administrative partners being allegedly not rigorous in scrutinizing statistics and the content of documentation uploaded on the database, rank-and-file lawyers generally were keen to emphasize that the system engenders a flow of visibility that administrators can use, at least in theory, for disciplinary purposes. Interestingly, flows of disciplinary and self-disciplinary power developed around the 
KMS not only through the (potential) role of administrators as agents of surveillance, but also through the active participation of rank-and-file lawyers in scrutinizing one another's work that was readily available on the database. As a result, boundaries between agents and targets of surveillance, and controllers and controlees are more blurred than ever. Seeing and being seen are no longer uncoupled - KMS users can see the work done by others at any time, and are also asked to present their own work to be seen by others. Other unanticipated ramifications of the bureaucratization of surveillance unfolded, such as the blooming of unofficial markets of knowledge - a classic resistance strategy that we can summarize as "attempting to hide from surveillance". This strategy, however, does not completely succeed in protecting the "deviants" from the gaze of lateral surveillance since most in the firm are apparently aware of the existence of the informal markets. Furthermore, another modality of resistance developed, which consists of "showing off". Far from attempting to hide from the gaze of unknown watchers, a number of actors strategically use the KMS to display their expertise and strengthen their reputation, which implies that "being seen" cannot be conceived of as a purely passive process. One can decide, and of course manipulate, what others should see of her/himself.

The surveillance literature indicates that, while for a variety of reasons the majority of people quite docilely comply with instruments of contemporary surveillance (Rouvroy \& Berns, 2010), the ways in which the instruments are appropriated and responses of the actors involved are not homogeneous (Haggerty \& Ericson, 2000, 2006). Accordingly, our study indicates that, in the context of a specific office of a professional service firm, the digitalization of surveillance translated into complex flows of obedience, compromise and resistance. Taking into account these complex trajectories is paramount if one wants to understand what surveillance is and how disciplinary mechanisms operate in an increasingly computerized society. Our findings do not invalidate, as such, the metaphor of the panopticon as a sense-making device. Disciplinary technologies that aim to create compliance through the fear of being seen as abnormal still constitute a significant aspect in the governance of people (Lyon, 2006). Yet we argue that the metaphor is significantly limited in dealing with the intricacies of today's surveillance, especially in the context of digitalized control systems. In particular, our analysis brings to the fore the prominent role of lateral observation (instead of hierarchical observation) as one of the main drivers of rhizomatical surveillance. Drawing extensively on the panoptical metaphor to make 
sense, interpret and study computerized control and surveillance is likely to oversimplify the processes by which disciplinary and self-disciplinary power now operates.

\section{Conclusion}

May (2001, p. ix) points out the need for research on contemporary surveillance:

In the face of such important issues [on contemporary surveillance] and the spread of these practices, clarity of thinking about their modes of operation, rationale for implementation and consequences for human actions and society as a whole, is often in short supply and even absent.

Accordingly, the present paper contributes to a better understanding of present-day surveillance practices and their behavioural effects, through a longitudinal socio-ethnographic study of the ramifications of surveillance that developed as a result of the implementation of a KMS in the Parisian legal and tax office of one of the world's largest public accounting firms. Our analysis essentially stresses that the use of the KMS in the case firm unexpectedly fostered the constitution of a lateral network of surveillance whereby colleagues and peers are involved in scrutinizing the validity of one another's work, irrespective of the office's hierarchies and official lines of specialization. This network is not primarily produced through the fear of abnormality being spotted by some hierarchical watcher, but develops through practitioners' day-to-day interactions with the KMS.

At the end of data collection, a majority of the lawyers in the Parisian office comply, with varying degrees of enthusiasm, with the injunction to share their tax and legal opinion letters through the KMS, despite the absence of any formal significant sanction and reward policy. On this basis, it appears that the KMS was more enabling than constraining. However, a number of lawyers were found to divert and circumvent the original agenda underlying the implementation of the KMS. Two main resistance strategies were mobilized in this respect - the development of unofficial markets of knowledge outside of the centralized KMS (which can be understood as "hiding") and the development of new games of visibility involving the purposeful selfdisclosure of one's work (which can be understood as "showing off").

Our study reinforces the claim that control mechanisms in real-life settings do not operate deterministically but with complex, lateral and unanticipated effects. The technologies of control 
and governance, which are used across society to regulate the lives of individuals (Miller \& Rose, 1990), do not transform the world in predictable ways. Our study therefore points to the importance of nuancing our views regarding the powers of such technologies in governing people and in influencing their subjectivities. In particular, the classic imagery of Bentham's panopticon is characterized with important limitations, as a sense-making device, in understanding the interplay of power and surveillance in contemporary settings, especially when digitalization is involved. In such settings, hierarchical panopticism downplays the subtlety and complexity of real-life disciplinary situations. Not only did the implementation of the KMS in the firm under study engender the panoptical control of the many by the few (at least in the eyes of the many), but it also translated into a significant movement, in which the many are laterally involved in the control of the many. In lateral surveillance no one is centrally positioned in an observatory position. The boundaries between the agents and targets of surveillance are more blurred than ever, with a constellation of watching gazes being provided by rank-and-file lawyers, who do not behave only as targets of surveillance but are also actively involved as watchers.

To sustain our point further, in Jeremy Bentham's archetypal prison, subjects are classified in ready-made cells. In FirmXLegalParis, on the contrary, the subjects participate, to a significant extent, in the very construction and institutionalization of the virtual cells which are used to categorize them. The lawyers are instrumental in attributing, through the knowledge committee instead of the office managing partner, the "best practice" tag to a select number of opinion letters in the KMS. ${ }^{13}$ Rank-and-file lawyers also play a significant role, more than that of the office managing partner, in enforcing the official taxonomy of expertise, for instance by complaining about those who deviate from it. An important implication is that the few at the top of the hierarchy cannot unilaterally impose a specific regime of truth to the many below. Patterns of truth (regarding what is normal and abnormal) are rather collectively constructed from the games of visibility in which rank-and-file lawyers actively participate. The lawyers therefore contribute to the spread of the surveillance and normalizing mechanisms that aimed initially to limit their own autonomy - but which are paradoxically recreated in a web of enabling and constraining ways, not least in providing lawyers with a playing field to be aware of what their

\footnotetext{
${ }^{13}$ The managing partner does not sit on the knowledge management committee and is not formally involved in the process of attributing Best Practice tags.
} 
peers are doing, and to elaborate and disseminate reputational signals. Thus, what can be viewed as an initiative that constrains professional autonomy also translates into a range of opportunities.

Importantly, the development of a network of lateral surveillance legitimizes the KMS while endorsing the original view sustaining its creation, namely, that knowledge can be made more transparent and can be reused in other engagements. Our study, therefore, reinforces the point made by Dirsmith et al. (1997), that rank-and-file practitioners in large accounting firms, in resisting the deployment of administrative systems, paradoxically endorse, through informal means such as mentoring, several of the same values which underlie these systems. Such paradoxes are unlikely to be unveiled by resorting to a strict adherence to the panoptical imagery.

In sum, our findings point to the spread of a surveillance regime where no one is really in command, but in which diverse and informal networks affect, through the fear of being watched and reliance on impression management techniques, the domain of social relationships while transforming the scope and meaning of information technologies. The ramifications engendered by the interplay between visibility and control are not innocuous. Within the office under study, one can be concerned about the extent of untrustworthiness encouraged through an institutional climate characterized by lateral surveillance, where lawyers are keenly aware that they are involved in complex games of power and visibility.

We do, however, recognize that some traits of panopticism are still apparent in the field. The possibility of managerial intervention (i.e., the office managing partner's theoretical ability to use the KMS to control people's work) has social effects and provokes behavioural changes, exactly like the possibility of being seen by a central but hidden watcher fosters self-control into prisoners. As such, the ramifications of surveillance that we have uncovered do not supersede panoptical mechanisms but amalgamate with them in complex ways (Lyon, 2006).

We suggest that the common denominator between panoptic-like control and rhizomatic surveillance is the central role played by the notion of visibility - visibility to others, visibility to the self, as well as the fear or preoccupation of being visible or invisible to others. These perspectives are all centre-stage in the development of ramifications ensuing from the use of bureaucratized control. Of course, the fear of being seen in certain ways can translate into impression management (Roberts, 2009), whereby actors purposively seek to promote certain representations of the self. This leads us to surmise that Goffman's (1959) classic notions of front 
stage, backstage and impression management are undeniably pertinent today in trying to understand social life, in this age where sophisticated technologies of communication and surveillance abound.

As pointed out by Baxter and Chua (2003), there is a need for management accounting research to examine how control and surveillance are enacted in highly digitalized contexts. Accordingly, and in light of our findings, we argue that accounting researchers need to deploy their analytical gaze in ways that take into account the complexities, ambiguities and paradoxes which characterize today's rhizomatic forms of control and surveillance. This is a difficult task since one of the greatest challenges confronting surveillance studies is to develop a grasp on the chaos and cacophony that underlie the spread of surveillance in organizations and society (Gilliom, 2006). As we illustrate in the paper, Foucault can be very useful in making sense of this cacophony - as long as researchers look beyond the confines of the panoptical conceptualization which, quite paradoxically, Foucault helped to make fashionable. 


\section{References}

\section{Non academic (Press) articles}

Deglise, F. (2009, January 24). La liberté mise en jeu. Le Devoir.

News.cnet.com (2003, January 13). RFID tags: Big Brother in small packages.

News.fr.msn.com/m6-actualite (2009, November 5). Souriez vous êtes fichés.

Reuters (2010a, April 25). Goldman's "Fabulous" Fab's conflicted love letters.

Reuters (2010b, May 6). Stock selloff may have been triggered by a trader error.

The Huffington Post (2010, May 6). Citigroup trading error, wrong price for $\mathrm{P} \& \mathrm{G}$ stock said to have fuelled stock plunge.

The Independent (2008, November 1). Virgin Atlantic sacks 13 staff for calling its flyers "chavs". The New York Times (2006, June 11). For some, online persona undermines a resume.

\section{Academic articles}

Armstrong, P. (1994). The influence of Michel Foucault on accounting research. Critical Perspective on Accounting, 5(1), 25-55.

Arnold, P. J. (1998). The limits of postmodernism in accounting history: The Decatur experience. Accounting, Organizations and Society, 23(7), 665-684.

Badiou, A. (2003). Infinite thoughts. London: Continuum.

Baumard, P., Donaka, C., Ibert, J., \& Xuereb, J.-M. (1999). La collecte des données et la gestion de leurs sources. In R.-A. Thiétart (Ed.), Méthodes de recherche en management (pp. 224256). Paris: Dunod.

Baxter, J., \& Chua, W. F. (2003). Alternative management accounting research - Whence and whither. Accounting, Organizations and Society, 28(2/3), 97-126.

Beaud, S., \& Weber, F. (1997). Guide de l'enquête de terrain. Paris: La Découverte.

Berg, B. L. (1989). Qualitative research methods for the social sciences. Boston: Allyn and Bacon.

Bevir, M. (1999). Foucault, power and institutions. Political Studies, 47(2), 345-359.

Blackler, R., Reed, M., \& Whitaker, A. (1993). Epilogue. An agenda for research. Journal of Management Studies, 30(6), 1017-1020.

Bogard, W. (2006). Welcome to the society of control: The simulation of surveillance revisited. In K. D. Haggerty \& R. V. Ericson (Eds.), The new politics of surveillance and visibility (pp. 55-78). Toronto: University of Toronto Press.

Brint, S. (1994). In an age of experts: The changing role of professionals in politics and public life. Princeton: Princeton University Press.

Carmona, S., Ezzamel, M., \& Gutíerrez, F. (1997). Control and cost accounting practices in the Spanish Royal Tobacco Factory. Accounting, Organizations and Society, 22(5), 411-446.

Carmona, S., Ezzamel, M., \& Gutíerrez, F. (2002). The relationship between accounting and spatial practices in the factory. Accounting, Organizations and Society, 27(3), 239-274.

Castells, M. (2001). The Internet galaxy: Reflections on the Internet, business, and society. Oxford, England: Oxford University Press.

Covaleski, M. A., Dirsmith, M. W., Heian, J. B., \& Samuel, S. (1998). The calculated and the avowed: Techniques of discipline and struggles over identity in Big Six public accounting firms. Administrative Science Quarterly, 43(2), 293-327.

Desanctis, G., \& Poole, M. S. (1994). Capturing the complexity in advanced technology use: Adaptive structuration theory. Organization Science, 5(2), 121-147. 
Dirsmith, M. W., Fischer, M. J., \& Samuel S. (2005). The socio-political constitution of expert systems and global knowledge expertise within Big 5(4) public accounting firms. International Journal of Technology, Policy and Management, 5(4), 361-387.

Dirsmith, M. W., Heian, J. B., \& Covaleski, M. A. (1997). Structure and agency in an institutionalized setting: The application and social transformation of control in the Big Six. Accounting, Organizations and Society, 22(1), 1-27.

Douglas, M. (1992). Blame and risk: Essays in cultural theory. New York: Routledge.

Doyle, A. (2006). An alternative current in surveillance and control: Broadcasting surveillance footage of crimes. In K. D. Haggerty \& R. V. Ericson (Eds.), The new politics of surveillance and visibility (pp. 199-224). Toronto: University of Toronto Press.

Dreyfus, H. L., \& Rabinow, P. (1983). Michel Foucault: Beyond structuralism and hermeneutics, second edition. Chicago: University of Chicago Press.

Ezzamel, M., Willmott, H., \& Worthington, F. (2004). Accounting and management-labour relations: The politics of production in the "factory with a problem". Accounting, Organizations and Society, 29(3/4), 269-302.

Flyvbjerg, B. (2001). Making social science matter: Why social inquiry fails and how it can succeed again. Cambridge, England: Cambridge University Press.

Foucault, M. (1977). Discipline and punish: The birth of the prison. New York: Vintage Books.

Foucault, M. (1980). Histoire de la sexualité 1 - La volonté de savoir. Paris: Éditions Gallimard.

Foucault, M. (1982). The subject and power. Critical Inquiry, 8(4), 777-795.

Foucault, M. (1983). Afterword: The subject and power. In H. L. Dreyfus \& P. Rabinow (Eds.), Michel Foucault: Beyond structuralism and hermeneutics, second edition (pp. 208-226). Chicago: University of Chicago Press.

Foucault, M. (2003). Abnormal. Lectures at the Collège de France 1974 -1975. London: Verso.

Freidson, E. (2001). Professionalism, the third logic: On the practice of knowledge. Chicago: University of Chicago Press.

Froud, J., Williams, K., Haslam, C., Johal, S., \& Williams, J. (1998). Caterpillar: Two stories and an argument. Accounting, Organizations and Society, 23(7), 685-708.

Gendron, Y., \& Spira, L. F. (2009). What went wrong? The downfall of Arthur Andersen and the construction of controllability boundaries surrounding financial auditing. Contemporary Accounting Research, 26(4), 987-1027.

Giddens, A. (1985). The nation-state and violence. Cambridge: Polity Press.

Gilliom, J. (2006). Struggling with surveillance: Resistance, consciousness, and identity. In K. D. Haggerty \& R. V. Ericson (Eds.), The new politics of surveillance and visibility (pp. 111129). Toronto: University of Toronto Press.

Glaser, B. G., \& Strauss A. L. (1967). The discovery of grounded theory: Strategies for qualitative research. New York: Aldine.

Goffman, E. (1959). The presentation of self in everyday life. Garden City, New York: Doubleday.

Gordon, D. R. (1987). The electronic panopticon: A case study of the development of the National Criminal Records System. Politics \& Society, 15(4), 483-511.

Gottschalk, P. (2005). Strategic knowledge management technology. Hershey, Pennsylvania: Idea Group.

Grey, C. (1998). On being a professional in a "Big Six" firm. Accounting, Organizations and Society, 23(5/6), 569-587.

Haggerty, K. D., \& Ericson, R. V. (2000). The surveillant assemblage. British Journal of Sociology, 51(4), 605-622. 
Haggerty, K. D., \& Ericson, R. V. (2006). The new politics of surveillance and visibility. In K. D. Haggerty \& R. V. Ericson (Eds.), The new politics of surveillance and visibility (pp. 3-25). Toronto: University of Toronto Press.

Han, B. (2002). Foucault's critical project: Between the transcendental and the historical. Stanford, California: Stanford University Press.

He, W., Fang, Y., \& Wei, K. K. (2009). The role of trust in promoting organizational knowledge seeking using knowledge management systems: An empirical investigation. Journal of the American Society for Information Science and Technology, 60(3), 526-537.

Hopwood, A. G. (1973). An accounting system and managerial behaviour. Lexington: Lexington Books.

Hoskin, K. W. \& Macve, R. H. (1986). Accounting and the examination: A genealogy of disciplinary power. Accounting, Organizations and Society, 11(2), 105-136.

Hoskin, K. W. \& Macve, R. H. (1988). The genesis of accountability: The West Point connections. Accounting, Organizations and Society, 13(1), 37-73.

Knights, D., Noble, F., Vurdubakis, T., \& Wilmott, H. (2001). Chasing shadows: Control, virtuality and the production of trust. Organization Studies, 22(2), 311-337.

Langley, A. (1999). Strategies for theorizing from process data. Academy of Management Review, 24(4), 691-670.

Latour, B. (1987). Science in action. Cambridge, Massachusetts: Harvard University Press.

Lazega, E. (2001). The collegial phenomenon. The social mechanisms of cooperation among peers in a corporate law partnership. Oxford: Oxford University Press.

Lincoln, Y., \& Guba, E. (1985). Naturalistic enquiry. New York: Sage Publications.

Lyon, D. (2001). Surveillance society: Monitoring everyday life. Buckingham, England: Open University Press.

Lyon, D. (2006). 9/11, synopticon, and scopophilia: Watching and being watched. In K. D. Haggerty \& R. V. Ericson (Eds.), The new politics of surveillance and visibility (pp. 35-54). Toronto: University of Toronto Press.

Macintosh, N. B. (1994). Management accounting and control systems: An organizational and behavioral approach. Chichester, England: Wiley.

Malsch, B., Gendron, Y, \& Grazzini, F. (2011). Investigating interdisciplinary translations: The influence of Pierre Bourdieu on accounting literature. Accounting, Auditing \& Accountability Journal, 24(2), 194-228.

Martinez, D. E. (2011). Beyond disciplinary enclosures: Management control in the society of control. Critical Perspectives on Accounting, 22(2), 200-211.

May, T. (2001). Series editor's foreword. In D. Lyon (Ed.), Surveillance society: Monitoring everyday life (pp. vii-x). Toronto: University of Toronto Press.

McKinlay, A., \& Pezet, E. (2010). Accounting for Foucault. Critical Perspectives on Accounting, 21(6), 486-495.

Miller, P., \& O'Leary, T. (1987). Accounting and the construction of the governable person. Accounting, Organizations and Society, 12(3), 235-265.

Miller, P., \& Rose, N. (1990). Governing economic life. Economy and Society, 19(1), 1-31.

Nealon, J. (2008). Foucault beyond Foucault. Power and its intensifications since 1984. Stanford, CA: Stanford University Press.

Neu, D., \& Graham, C. (2006). The birth of a nation: Accounting and Canada's first nations, 1860-1900. Accounting, Organizations and Society, 31(1), 47-76.

Orlikowski, W. (2007). Sociomaterial practices: Exploring technology at work. Organization Studies, 28(9), 1435-1448. 
Poster, M. (1997). The second media age. Cambridge, Massachusetts: Polity Press.

Potte-Bonneville, M. (2010). Surveillance, contrôle, gouvernement: L'ADN du contemporain. De l'actualité de la pensée de Michel Foucault au travers de l'exemple polémique des "tests génétiques". Multitudes, 40(1), 68-76.

Preston, A. M. (1989). The taxman cometh: Some observations on the interrelationship between accounting and inland revenue practice. Accounting, Organizations and Society, 14(5/6), 389-413.

Quessada, D. (2010). De la sousveillance. La surveillance globale, un nouveau mode de gouvernementalité. Multitudes, 40(1), 54-59.

Quessada, D., \& Sadin. E. (2010). Big Brother n'existe pas, il est partout. Multitudes, 40(1), 7887.

Rabinow, P. (1984). Introduction. In P. Rabinow (Ed.), The Foucault reader (pp. 3-29). New York: Pantheon Books.

Rahaman, A., Neu, D., \& Everett, J. (2010). Accounting for social purpose alliances: Confronting the HIV/AIDS pandemic in Africa. Contemporary Accounting Research, 27(4), 1093-1129.

Reed, M. (1996). Expert power and control in late modernity: An empirical review and theoretical synthesis. Organization Studies, 17(4), 573-597.

Roberts, J. (2009). No one is perfect: The limits of transparency and an ethic for "intelligent" accountability. Accounting, Organizations and Society, 34(8), 957-970.

Robson, K., Willmott, H., Cooper, D., \& Puxty, T. (1994). The ideology of professional regulation and the market for accounting labour: Three episodes in the recent history of the U.K. accountancy profession. Accounting, Organizations and Society, 19(6), 527-553.

Rouvroy, A., \& Berns, T. (2010). Le nouveau pouvoir statistique ou quand le contrôle s'exerce sur un réel normé, docile et sans événement car constitué de corps numériques. Multitudes, 40(1), 88-103.

Sadin, E. (2010). Le nouveau paradigme de la surveillance. Cerner l'humain par l'entrelacs du marketing et de la sécurité. Multitudes, 40(1), 60-66.

Sikka, P. (2009). Financial crisis and the silence of the auditors. Accounting, Organizations and Society, 34(6/7), 868-873.

Suddaby, R., Gendron, Y., \& Lam, H. (2009). The organizational context of professionalism in accounting. Accounting, Organizations and Society, 34(3/4), 409-427.

Tisseron, S. (2008). Virtuel, mon amour: Penser, aimer, souffrir à l'ère des nouvelles technologies. Paris: Albin Michel.

Townley, B. (1993). Foucault, power/knowledge, and its relevance for human resource management. Academy of Management Review, 18(3), 518-545.

Townley, B. (1994). Reframing human resource management: Power, ethics and the subject at work. Thousand Oaks, California: Sage Publications.

Van Maanen, J. (1988). Tales of the field: On writing ethnography. Chicago: University of Chicago Press.

Walker, S. P. (2010). Child accounting and "the handling of human souls". Accounting, Organizations and Society, 35(6), 628-657.

Walsh, E. J., \& Stewart, R. E. (1989). Accounting and the construction of institutions: The case of a factory. Accounting, Organizations and Society, 18(7/8), 783-800.

Weick, K. (1989). Theory construction as disciplined imagination. Academy of Management Review, 14(4), 516-531. 
Wood, D. M. (2007). Beyond the panopticon? Foucault and surveillance studies. In J.W. Crampton \& S. Elden (Eds.), Space, knowledge and power: Foucault and geography (245264). Burlington, Vermont: Ashgate Publishing Company. 